\title{
In-silico molecular design of heterocyclic benzimidazole scaffolds as prospective anticancer agents
}

\author{
Sumit Tahlan', Sanjiv Kumar' , Kalavathy Ramasamy ${ }^{2,3}$, Siong Meng Lim²,3, Syed Adnan Ali Shah", \\ Vasudevan Mani ${ }^{5}$ and Balasubramanian Narasimhan ${ }^{1 *}$ (D)
}

\begin{abstract}
Benzimidazole is a valuable pharmacophore in the field of medicinal chemistry and exhibit wide spectrum of biological activity. Molecular docking technique is routinely used in modern drug discovery for understanding the drugreceptor interaction. The selected data set of synthesized benzimidazole compounds was evaluated for its in vitro anticancer activity against cancer cell lines (HCT116 and MCF7) by sulforhodamine B (SRB) assay. Further, molecular docking study of data set was carried out by Schrodinger-Maestro v11.5 using CDK-8 (PDB code: 5FGK) and ER-alpha (PDB code: 3ERT) as possible target for anticancer activity. Molecular docking results demonstrated that compounds 12, 16, N9, W20 and Z24 displayed good docking score with better interaction within crucial amino acids and corelate to their anticancer results. ADME results indicated that compounds $\mathbf{1 6}, \mathbf{N} \mathbf{9}$ and $\mathbf{W} \mathbf{2 0}$ have significant results within the close agreement of the Lipinski's rule of five and Qikprop rule within the range and these compounds may be taken as lead molecules for the discovery of new anticancer agents.
\end{abstract}

Keywords: Benzimidazoles, Anticancer activity, Docking, CDK-8, ER-alpha, ADME

\section{Introduction}

Benzimidazole is an important structural motif found in extensive number of natural and pharmacologically active compound [1]. The benzimidazole ring itself is an urgent pharmacophore in present day and has been used as privileged scaffolds to synthesize selective drugs of interest in medicinal field including antiulcer [2], antioxidant [3], HIV-RT inhibitor [4], anticancer [5], antihelmintic [6], antimicrobial [7], antihistamine [8] etc. The selected marketed drugs having benzimidazole moiety (Fig. 1) i.e. veliparib (a), glasdegib (b), liarozole (c), crenolanib (d), abemaciclib (e), pracinostat (f), bendamustine (g) nocodazole $(\mathrm{h})$.

Presently used chemotherapeutic agents restrain the growth of tumour through suppression of DNA replication and transcription. Nevertheless, the attempt of

\footnotetext{
*Correspondence: naru2000us@yahoo.com

${ }^{1}$ Faculty of Pharmaceutical Sciences, Maharshi Dayanand University, Rohtak 124001, India
}

Full list of author information is available at the end of the article discovering new curative anticancer agents in last decade has led to targets of specific molecular modifications in tumour cells. The new approach now focuses mainly on the development of small biologically active molecules containing significant activity without toxicity related to the usual chemotherapy [9]. The human CDK8 protein which is a part of the RNA polymerase has been one of the proteins responsible for acute lymphoblastic leukaemias.

CDK activity is controlled by association with regulatory subunits (cyclins) and CDK inhibitor proteins, by their phosphorylation state and by ubiquitin-mediated proteolysis. Since the loss of cell cycle control leading to deregulated cell proliferation is one of the hallmarks of cancer, it is anticipated that the inhibition of CDKs will provide an effective approach to control tumor growth and therefore have an impact on cancer therapy. Inhibition of CDKs has been studied by many organizations and has been achieved using a variety of structural 


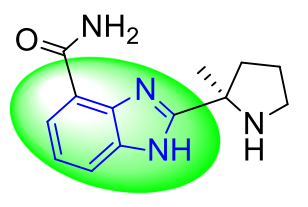

a

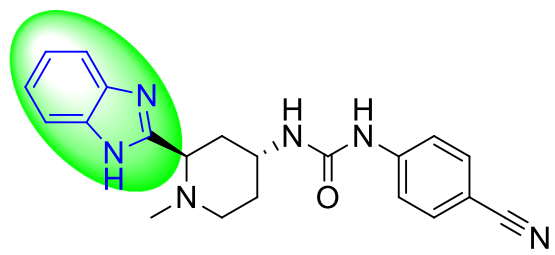

b

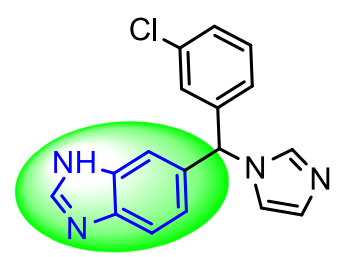

C<smiles>CC1(COc2cccc3c2CCN(c2ccc4cccc(N5CCC(N)CC5)c4n2)C3)COC1</smiles><smiles></smiles>

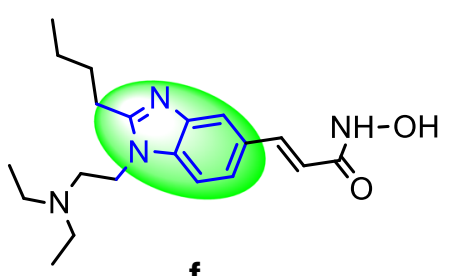

f

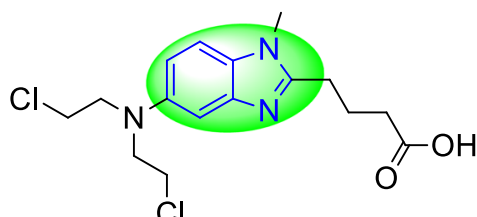

g

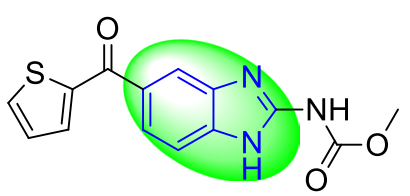

h

Fig. 1 The selected marketed drugs having benzimidazole moiety

templates with varying degrees of selectivity and activities [10].

Western blotting analysis was used to demonstrate that three hits target CDK8 in HCT 116 colorectal cancer cells. The results showcase the successful application of virtual screening cascades to identify CDK8-targeted scaffolds that can be developed into a drug discovery program. CDK8 is a cyclin-dependent kinase that forms part of the Mediator complex, which itself regulates the transcriptional activity of RNA polymerase II. A number of studies have shown that CDK8 modulates the transcriptional output from distinct transcription factors involved in oncogenic control. These factors include the Wnt $\beta$ catenin pathway, Notch, p53 and TGF- $\beta$. CDK8 has been found to be amplified and over expressed in colon cancer. In this context, CDK8 has been reported to act as a colon cancer oncogene. The role of CDK8 in both cellular signaling and colon cancer have relied upon RNAi mediated suppression of CDK8 and on the use of a kinase dead mutant CDK8. In order to more fully investigate the role of CDK8 in colon cancer, we aimed to develop a potent and selective small molecule inhibitor of CDK8 [11].

CDK-8 is a heterodimeric kinase protein responsible for regulation of cell cycle progression, transcription and other functions. CDKs require cyclin that provides additional sequences for enzymatic potential. All the CDKs $(1,4,5,7,8,9$ and 11) have a two-lobed structure$\mathrm{N}$-terminal having beta sheets and C-terminal composed of $\alpha$-helices [12, 13].

Estrogen signaling is essential in the initiation and development of human breast cancer. In the past several decades, extensive efforts have been dedicated to understand the underlying mechanisms of this important signaling pathway in human breast cancer, which have facilitated the development of anti-estrogen therapy, the first targeted therapy for human cancer. Estrogen biology is exceedingly complex and important in the development and function of numerous tissues and physiological phenomena [14, 15]. Computational approaches i.e. molecular docking used for modern drug discovery design for the medicinal drug [16]. Drug molecules might fail during development because of several reasons but as found by the researchers one of the major reasons of failures is related with poor pharmacokinetic: ADME properties [17]. Drug toxicity is the one of the major factors to withdraw drug from the market. Therefore, ADME properties are the crucial determinants for the clinical success of the drug [18]. Now these days, computer based drug design are employed to determine the ADME profile of the compound. ADME modeling has attracted the 
considerable attention of the pharmaceutical researchers for the drug discovery as they are high-throughput in nature and cost effective [19].

Recently, a greater emphasis has been given towards the researches on complementary and alternative medicine that deals with cancer management. The present study helps us to understand the interaction between the benzimidazoles and receptors

(CDK-8 and ER-alpha) and also explore their binding mode by in silico molecular design.

\section{Experimental}

\section{Materials and methods}

\section{Data set}

The data set of selected benzimidazole compounds have exhibited better anticancer activity towards human colorectal carcinoma cancer cell line (HCT116) was selected from the earlier study reported by Tahlan et al. [5, 7, 9, $20,21]$. The molecular structures of all reported compounds were drawn in ChemDraw Ultra software 12.0. The data set of selected benzimidazole compounds with their anticancer activity results is shown in Table 1 (S. No. 1 to 18$)$.

\section{Physicochemical and spectral interpretation data of most active compounds}

2-((1H-Benzo[d]imidazol-2-yl)thio)-N-(4-(2-(5-bromo2-hydroxybenzylidene)hydrazine-carbonyl)phenyl)acetamide (12) M.pt. ${ }^{\circ} \mathrm{C}:>300$; $\mathrm{R} f$ value: 0.52 ; \% yield: 85.87; IR: 3077 (C-H str.), 1439 (C=C str.), 1669 (-CONH str.), 1362 ( $\mathrm{N}=\mathrm{CH}$ str.), 1317 (C-N str.), 730 (C-S str.), 3629 (O-H str.), 625 (C-Br str.); ${ }^{1} \mathrm{H}-\mathrm{NMR}: 3.84$ (s, $\left.2 \mathrm{H}, \mathrm{CH}_{2}\right)$, $4.30(\mathrm{~s}, 1 \mathrm{H}, \mathrm{OH}), 4.31(\mathrm{~s}, 1 \mathrm{H}, \mathrm{NH}$ of imidazole), 6.77$7.93(\mathrm{~m}, 11 \mathrm{H}, \mathrm{Ar}-\mathrm{H}), 7.92\left(\mathrm{~s}, 2 \mathrm{H},(\mathrm{CONH})_{2}\right), 7.93$ (s, $1 \mathrm{H}, \mathrm{N}=\mathrm{CH}) ;{ }^{13} \mathrm{C}-\mathrm{NMR}: 36.76,111.0,118.3,118.8,119.4$, 121.0, 122.8, 125.8, 130.0, 132.1, 135.9, 139.1, 143.2, 150.1, 161.2, 158.1, 167.2; Anal. Calcd. for $\mathrm{C}_{23} \mathrm{H}_{18} \mathrm{~N}_{5} \mathrm{O}_{3} \mathrm{SBr}$ : C, 52.68; H, 3.46; N, 13.36; Found: C, 52.72; H, 3.50; N, 13.40; MS ES + (ToF): $m / z 527\left[\mathrm{M}^{+}+1\right]$.

2-((1H-Benzo[d]imidazol-2-yl)thio)-N-(3-(2-(2-methoxybenzylidene)hydrazinecarbonyl)-phenyl)acetamide (16) M.pt. ${ }^{\circ} \mathrm{C}$ : $122-125$; $\mathrm{R} f$ value: 0.80 ; \% yield: 75.42 ; IR: 3108 (C-H str.), 1606 (C=C str.), 1669 (-CONH str.), 1320 ( $\mathrm{N}=\mathrm{CH}$ str.), 1289 (C-N str.), 665 (C-S str.), 1247 (C-O-C str.), 2835 (C-H str., O- $\left.\mathrm{CH}_{3}\right)$; ${ }^{1} \mathrm{H}-\mathrm{NMR}$ : 7.04$8.26(\mathrm{~m}, 12 \mathrm{H}, \mathrm{Ar}-\mathrm{H}), 4.31$ (s, $1 \mathrm{H}, \mathrm{NH}$ of imidazole), 3.85 $\left(\mathrm{s}, 2 \mathrm{H}, \mathrm{CH}_{2}\right), 7.99\left(\mathrm{~s}, 2 \mathrm{H},(-\mathrm{CONH})_{2}\right), 8.26(\mathrm{~s}, 1 \mathrm{H}, \mathrm{N}=\mathrm{CH})$, $3.85\left(\mathrm{~s}, 3 \mathrm{H}, \mathrm{CH}_{3}\right) ;{ }^{13} \mathrm{C}-\mathrm{NMR}: 36.6,56.2,112.5,117.7$, $120.3,121.1,122.2,123.6,124.7,129.5,129.7,133.4,139.5$, 150.1, 159.2, 165.9, 167.5; Anal. Calcd. for $\mathrm{C}_{24} \mathrm{H}_{21} \mathrm{~N}_{5} \mathrm{O}_{3} \mathrm{~S}$ : C, 62.73; H, 4.61; N, 15.24; Found: C, 62.77; H, 4.65; N, 15.28; MS ES + (ToF): $m / z 462\left[\mathrm{M}^{+}+1\right]$.
4-(2-(1H-Benzo[d]imidazol-2-ylthio)acetamido)$\mathrm{N}$-(2,6-dimethylphenyl)benzamide (N9) $\mathrm{M} . \mathrm{pt} .{ }^{\circ} \mathrm{C}: 207-$ 210; Rf value: 0.56; \% yield: 64.03; IR: 3018 (C-H str.), 1598 (C=C str.), 1668 ( $-\mathrm{CONH}$ str.), $1360(\mathrm{~N}=\mathrm{CH}$ str.), 1281 (C-N str.), 713 (C-S str.), 2915 (C-H str., $\left.-\mathrm{CH}_{2}-\right), 2948$ (C-H str., $\left.\mathrm{CH}_{3}\right) ;{ }^{1} \mathrm{H}-\mathrm{NMR}$ : 7.16-7.96 (m, $\left.11 \mathrm{H}, \mathrm{Ar}-\mathrm{H}\right), 4.36$ (s, $1 \mathrm{H}, \mathrm{NH}$ of imidazole), $7.97\left(\mathrm{~s}, 2 \mathrm{H},(\mathrm{CONH})_{2}\right), 2.53$ (s, 6H, $\left.\left(-\mathrm{CH}_{3}\right)_{2}\right) ;{ }^{13} \mathrm{C}$-NMR: 39.0, 118.3, 121.6, 125.4, 130.4, 142.8, 149.7, 166.6, 166.8; Anal. Calcd. for $\mathrm{C}_{24} \mathrm{H}_{22} \mathrm{~N}_{4} \mathrm{O}_{2} \mathrm{~S}$ : C, 66.96; H, 5.15; N, 13.01; Found: C, 66.99; H, 5.19; N, 13.05; MS ES + (ToF): $m / z 431\left[\mathrm{M}^{+}+1\right]$.

3-(2-(1H-Benzo[d]imidazol-2-ylthio)acetamido)$\mathrm{N}$-ethyl-N-phenyl-benzamide (W20) $\quad \mathrm{M} . p t .{ }^{\circ} \mathrm{C}: 216-219$; $\mathrm{R} f$ value: 0.42; \% yield: 83.22; IR: 3096 (C-H str.), 1598 (C=C str.), 1336 ( $\mathrm{N}=\mathrm{CH}$ str.), 1304 (C-N str.), 1664 (CONH str.), 701 (C-S str.), 2932 (C-H str., $\left.\mathrm{CH}_{3}\right), 2826$ (C-H str., $\left.\mathrm{N}-\mathrm{CH}_{3}\right), 2915$ (C-H str., $\left.-\mathrm{CH}_{2}-\right)$; ${ }^{1} \mathrm{H}-\mathrm{NMR}$ : 7.12-8.33 (m, 13H, Ar-H), 4.31 (s, 1H, NH of imidazole), $7.82\left(\mathrm{~s}, 2 \mathrm{H},(\mathrm{CONH})_{2}\right), 2.51$ (q, $\left.2 \mathrm{H}, \mathrm{CH}_{2}\right) ;{ }^{13} \mathrm{C}-\mathrm{NMR}: 36.1$, 119.7, 119.7, 121.4, 123.1, 124.2, 129.0, 131.3, 139.0, 149.7, 166.4, 167.0; Mol. Formula $\mathrm{C}_{24} \mathrm{H}_{22} \mathrm{~N}_{4} \mathrm{O}_{2} \mathrm{~S}$; Elem. Anal. Calcd. C, 66.96; H, 5.15; N, 13.01; Found C, 66.93; H, 5.19; N, 13.04; MS: $m / z 431\left[\mathrm{M}^{+}+1\right]$.

1H-Benzo[d]imidazol-2-yl2-(2-(2-bromo-3-phenylallylidene)hydrazinyl)ethanethioate (Z24) M.pt. ${ }^{\circ} \mathrm{C}$ : 160 163; R $f$ value: 0.51 ; \% yield: 78.68; IR: 3087 (C-H str.), 1601 (C=C str.), 1713 (-CO str.), 1354 (C=N str.), $1337(\mathrm{C}-\mathrm{N}$ str.), 1176 (N-N str., hydrazide), 694 (C-S str.), 2843 (C-H str., $-\mathrm{CH}_{2}-$ ), 684 (C-Br str.), 1623 (conjugated $\mathrm{C}=\mathrm{C}$ and phenyl subst. $\mathrm{C}=\mathrm{C}) ;{ }^{1} \mathrm{H}-\mathrm{NMR}$ : 7.13-7.94 $(\mathrm{m}, 9 \mathrm{H}, \mathrm{Ar}-\mathrm{H})$, $7.06\left(\mathrm{~s}, 1 \mathrm{H}, \mathrm{NH}\right.$ of imidazole), $2.00\left(\mathrm{~s}, 2 \mathrm{H}, \mathrm{CH}_{2}\right), 7.06(\mathrm{~s}$, $1 \mathrm{H}, \mathrm{NH}), 12.55(\mathrm{~s}, 1 \mathrm{H}, \mathrm{N}=\mathrm{CH}), 7.19(\mathrm{~s}, 1 \mathrm{H}, \mathrm{Br}-\mathrm{C}=\mathrm{CH})$; ${ }^{13}$ C-NMR: 109.4, 122.1, 123.8, 128.6, 128.9, 130.5, 131.3, 132.2, 132.8, 150.1, 187.8; Mol. Formula $\mathrm{C}_{18} \mathrm{H}_{15} \mathrm{~N}_{4} \mathrm{OSBr}$; Elem. Anal. Calcd. C, 52.06; H, 3.64; N, 13.49; Found C, 52.02; $\mathrm{H}, 3.68 ; \mathrm{N}, 13.45 ; \mathrm{MS}: m / z 416\left[\mathrm{M}^{+}+1\right]$.

\section{Molecular docking Preparation of ligand structure}

The ligand structures of the data set were prepared by LigPrep module of Schrodinger v11.5. To give the best results, the structures that are docked must be good representations of the actual ligand structures as they would appear in a protein-ligand complex. This means that for Glide docking the structure must meet the following conditions. They must be three-dimensional (3D) form. Glide only modifies the torsional internal coordinates of the ligand during docking, so the rest of the geometric parameters must be optimized beforehand. They must each consist of a single molecule that has no covalent bonds to the receptor, with no accompanying fragments, 
Table 1 Data set of selected benzimidazole compounds with their anticancer results

\begin{tabular}{|c|c|c|c|c|}
\hline Series & S. no. & $\begin{array}{l}\text { Comp. } \\
\text { code }\end{array}$ & Molecular structure & $\begin{array}{l}\text { Cancer cell line } \\
\text { HCT116 }\left(\mathrm{IC}_{50}=\mu \mathrm{M}\right)\end{array}$ \\
\hline \multirow[t]{5}{*}{ I } & 1 & 5 & & 8.82 \\
\hline & 2 & 12 & & 9.53 \\
\hline & 3 & 20 & & 1.49 \\
\hline & 4 & 23 & & 1.70 \\
\hline & Std. & 5-FU & & 2.02 \\
\hline \multirow[t]{5}{*}{ II } & 5 & 12 & & 11.64 \\
\hline & 6 & 16 & & 11.97 \\
\hline & 7 & 19 & & 13.46 \\
\hline & 8. & 26 & & 7.32 \\
\hline & Std. & 5-FU & & 0.65 \\
\hline
\end{tabular}

such as counter ions and solvent molecules. They must have all their hydrogen (filled valences). They must have an appropriate protonation state for physiological $\mathrm{pH}$ values (around 7) [22, 23].

\section{Preparation of protein structure}

The selected proteins i.e. human cyclin-dependent kinase CDK-8 (PDB code: 5-FGK) and ER-alpha (PDB code: 3ERT) (Figs. 2 and 3) were obtained from the protein data bank (PDB) (http://www.rcsb.org/pdb/home/home. do). The imported typical structure file of protein from the protein data bank is not suitable for immediate use to carry out the molecular docking study. A typical PDB structure file consists of heavy atoms and may include a co-crystallized ligand, water molecules, metal ions and cofactors. The ligand and ligand-receptor complex is suitable for use with other Schrödinger modules. The protein structure was prepared using the protein preparation 
Table 1 (continued)

\begin{tabular}{|c|c|c|c|c|}
\hline Series & S. no. & $\begin{array}{l}\text { Comp. } \\
\text { code }\end{array}$ & Molecular structure & $\begin{array}{l}\text { Cancer cell line } \\
\text { HCT116 }\left(\mathrm{IC}_{50}=\right. \\
\mu \mathrm{M})\end{array}$ \\
\hline \multirow[t]{5}{*}{ III } & 9 & N8 & & 13.73 \\
\hline & 10 & N9 & & 5.85 \\
\hline & 11 & N14 & & 12.42 \\
\hline & 12 & N18 & & 4.53 \\
\hline & Std. & 5-Fu & & 9.99 \\
\hline \multirow[t]{5}{*}{ IV } & 13 & W12 & & 7.08 \\
\hline & 14 & W15 & & 23.12 \\
\hline & 15 & W17 & & 4.12 \\
\hline & 16 & W20 & & 11.61 \\
\hline & Std. & 5-Fu & & 7.69 \\
\hline \multirow[t]{3}{*}{ V } & 17 & Z24 & & 0.46 \\
\hline & 18 & Z27 & & 67.49 \\
\hline & Std. & 5-Fu & & 8.84 \\
\hline
\end{tabular}

wizard (preprocessed, optimized and minimized) in the Schrodinger software graphical user interface Maestro $v 11.5$ [24].

\section{Preparation of grid}

Grid generation is done using receptor grid generation module of maestro version 11.5. A grid is generated around the binding site already occupied by the co-crystallized ligand so that co-crystallized ligand can 

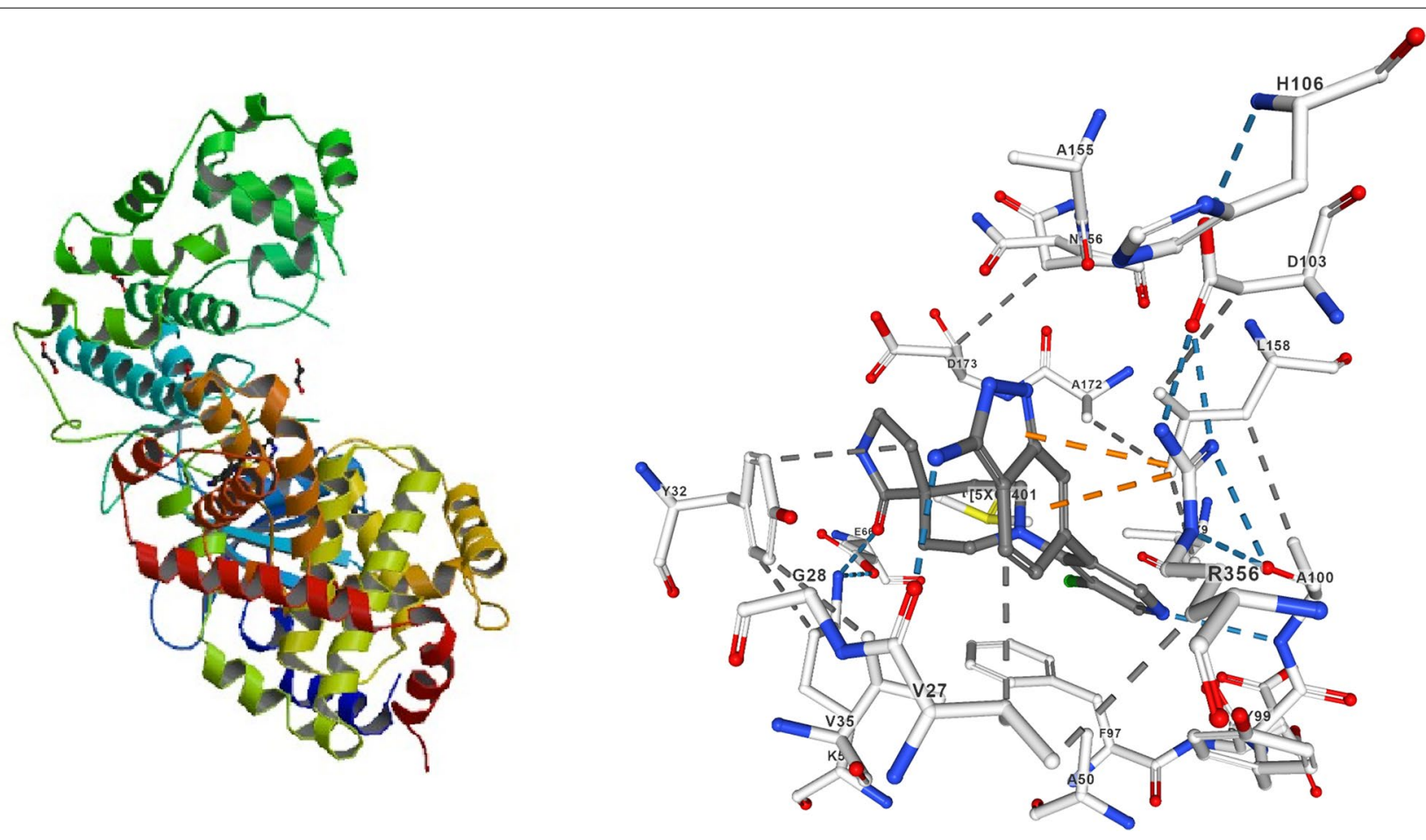

Fig. 2 Protein structure with $5 X$ G ligand (5FGK)
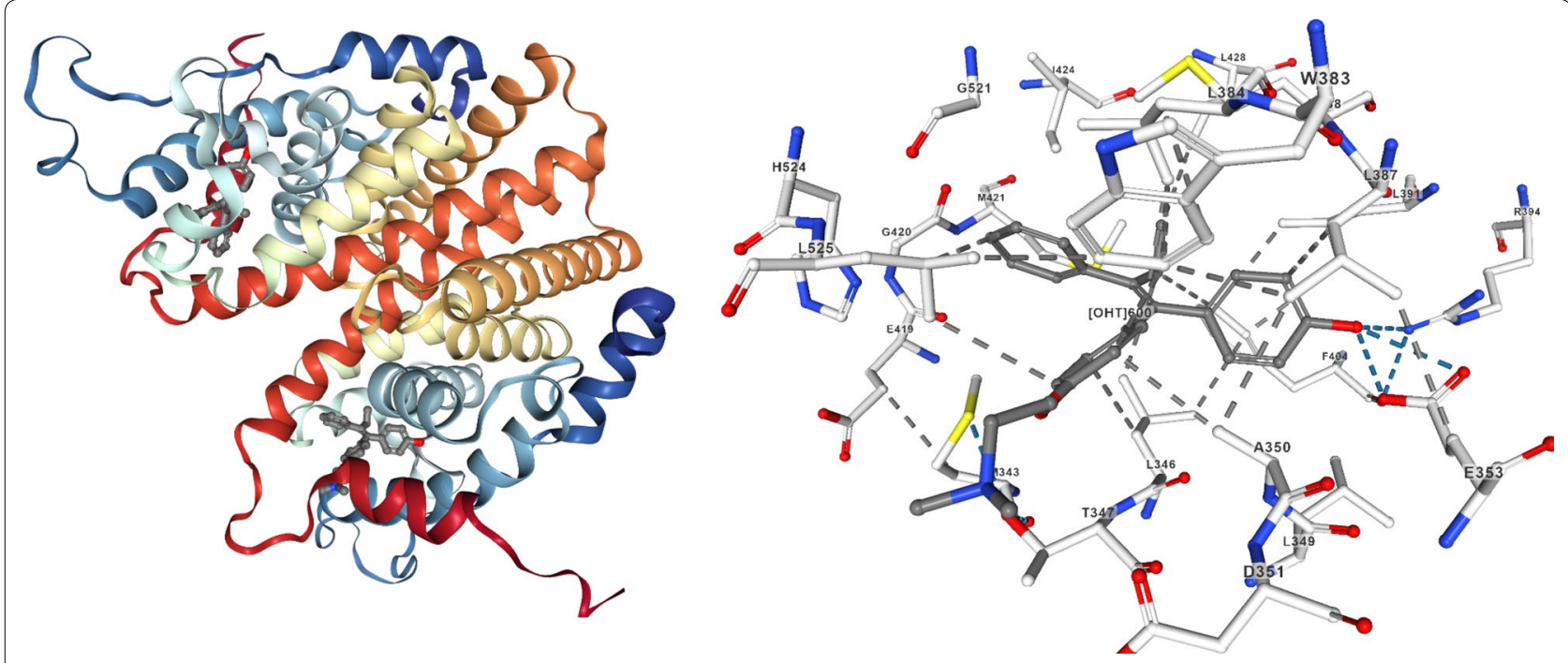

Fig. 3 Protein structure with OHT ligand (3ERT) 
be excluded and new compounds can be attached to the same binding site [25].

\section{Docking}

Molecular docking study was applied to investigate the binding mode of compound with selected PDB ID for cancer cell lines. Docking score obtained from GLIDE (maestro v11.5) and binding site was targeted and the grid was created. The active site grid covered the important amino acids interacting with receptor. The 3D structure of the protein was obtained from protein data bank using their specific (PDB code: 5FGK and ER-alpha PDB code: 3ERT). A data set of benzimidazoles was used as ligands and their structures were drawn using the workspace of Maestro and were converted to 3D form for the docking studies. The collected ligands were prepared for docking. Then the prepared ligands were docked into the generated grid in the prepared protein. The best docked pose with lowest glide score value was recorded for each ligand. Extra precision (XP) was performed using Schrödinger-maestro v11.5 (2018-1) [26-28].

\section{ADME prediction}

Theoretical calculation of the ADME properties of data set was calculated by QikProp. Nearly eleven physically significant descriptors and pharmacologically properties of the compounds were analyzed by QikProp. Aqueous solubility of compounds plays a key impact on many ADME associated properties like uptake, distribution, transport and ultimately bioavailability. The benzimidazole derivatives solubility values were within the range. Finally, the Lipinski's rule of five and Qikprop rule within the range for the benzimidazole derivatives and thus making these derivatives as suitable drug candidates [12].

\section{Anticancer evaluation $\left(I C_{50}\right)$}

The anticancer activity was determined by Sulforhodamine-B (SRB) assay. Briefly, HCT116 and MCF7 cancer cell lines were seeded onto the 96 well plate at 2500 cells/well. The cells were allowed to attach overnight before being exposed to the respective compounds $(0.01-100 \mu \mathrm{g} / \mathrm{mL})$ for $72 \mathrm{~h}$. The highest concentration of each compound tested $(100 \mu \mathrm{g} / \mathrm{mL})$ contained only $0.1 \%$ DMSO (non-cytotoxic) SRB assay was then performed whereby the cells were fixed using trichloroacetic acid for $30 \mathrm{~min}$ at $4{ }^{\circ} \mathrm{C}$ and stained with $0.4 \%(\mathrm{w} / \mathrm{v})$ SRB mixed with $1 \%$ acetic acid for $15 \mathrm{~min}$. After five washes with $1 \%$ acetic acid solution, the protein-bound dye was extracted with $10 \mathrm{mM}$ tris base solution. Optical density was read at $570 \mathrm{~nm}$ and $\mathrm{IC}_{50}$ of each compound was determined. Anticancer results were presented as mean $\mathrm{IC}_{50}$ of at least triplicates (Tables 3 and 4) [29].

\section{Results and discussion \\ Target identification}

Kinase inhibitors are very efficacious for the treatment of cancer especially targeting specific mutations that chiefly drive tumorigenesis. They are categorized according to their capacity to catalyze the transfer of the terminal phosphate of ATP to the substrates that usually contain a serine, threonine or tyrosine residue [30]. Cyclindependent kinases (CDKs) are a family of key regulatory proteins that oversee diverse cellular events and their main involvement is in the cell cycle and transcription. Given the fundamental biological roles CDKs perform, it is not surprising that their aberrant activities are a common feature of many diseases, especially cancer. CDKs are a family of serinethreonine protein kinases that govern the initiation, progression and completion of the cell cycle. Activity of the CDKs allows the orderly transition between phases of the cell cycle. Inhibition of cell cycle progression and apoptosis are the most common causes of cell growth inhibition. Cell cycle progression is induced by various cell cycle proteins such as CDKs and cyclins as they are the key regulators of cell cycle [31]. Existing CDK8 X-ray crystal structures have unresolved regions in the vicinity of the ATP-binding site. Thus, homology modeling was used to generate two complete and optimal structural models. The target structure should be determined experimentally by either X-ray crystallography or nuclear magnetic resonance, which can be downloaded from PDB; however, docking has been performed successfully in comparison to homology models or threading. The model should have good quality. It can be tested using validation software such as Molprobity [32].

\section{Molecular docking results}

Molecular docking study was carried out to analyses the binding mode of the compounds against human colorectal carcinoma and breast adenocarcinoma cancer cell lines. Ligand interaction showed the binding mode of compound and standard drugs in the active site of CDK8 (PDB id: 5FGK) have good resolution about 
$2.36 \AA$, co-crystallized ligand (5XG) was selected for docking study. Root-mean-square deviation (RMSD) value of docked poses of native co-crystallized ligand is $0.10 \AA$, R-value free is 0.237 and ER-alpha (PDB id: 3ERT) have good resolution about $1.9 \AA$, co-crystallized ligand $(\mathrm{OHT})$ was selected for docking study. RMSD value of docked poses of native co-crystallized ligand is $2.0 \AA$. R-value free is 0.262 . Docking study of the data set showed good docking score and interaction with crucial amino acids residues in the binding pocket of the receptor (Table 2). The molecular docking results demonstrated in terms of negative energy value that the lower the binding energy value, best would be the binding affinity with the receptor [33]. Docking results with cdk-8 protein, compounds 12, 16, N9, W20 and Z24 were found to be best molecules and showed better docking score at target site of protein and displayed good to moderate anticancer activity against cancer cell line (HCT116). If we look into the binding mode of compound 12, exhibited good docked score $(-8.907)$ and formation of hydrogen bond with amino acids i.e. Asp173, Ala100 and Lys52 with oxygen and nitrogen atoms. The binding mode of compound 16 have docking score $(-7.69)$ and developed of hydrogen bond with amino acids (Lys52 and Ala155) with oxygen atom of $\mathrm{OCH}_{3}$ and nitrogen atom of benzimidazole ring, respectively. The binding mode of compound N9 exhibited good docking score $(-7.425)$ and prepared hydrogen bond with amino acids (Lys52, Tyr32 and Val27) with oxygen atom and nitrogen atoms of benzimidazole ring, respectively. Compound W20 showed good docking score $(-9.686)$ and prepared hydrogen bond with amino acids (Ala100 and Ala155) with oxygen and nitrogen atoms of benzimidazole ring, respectively. Compound Z24 displayed the good docking score $(-7.295)$ and developed hydrogen bond with amino acids (Tyr32 and Val27) with oxygen and nitrogen atoms, respectively. Standard drugs (5-fluorouracil) have good docking score $(-5.79)$ and formation of hydrogen bond with amino acids residues (Ala100 and Asp98) with oxygen and nitrogen atoms of 5-fluorouracil, respectively. These compounds showed better docked score than the standard drug and the docking results also correlate to their anticancer activity results. The docking results with interacting residues of the docked compounds and standard drug are shown in Table 3; binding surface (3D) and ligand interaction (2D) images are shown in Figs. 4, 5, 6, 7, 8, 9 .

Further, the selected data set was docked with ERalpha receptor of MCF7 (PDB id: 3ERT). Among the docked data set, compounds 12, 16, N9, W20 and Z24 also showed the good docked score and glide energy with crucial amino acids residues in the binding pocket of the receptor. If we look into the binding mode of compound 12 have docking score $(-8.825)$ and

Table 2 Docking results of the selected benzimidazole compounds

\begin{tabular}{|c|c|c|c|c|c|c|}
\hline \multirow[t]{2}{*}{ Series } & \multirow[t]{2}{*}{ S. no. } & \multirow[t]{2}{*}{ Comp. code } & \multicolumn{2}{|l|}{ CDK8 (HCT116) } & \multicolumn{2}{|l|}{ 3ERT (MCF7) } \\
\hline & & & Docking score & $\begin{array}{l}\text { Glide energy (kcal/ } \\
\text { mol) }\end{array}$ & Docking score & $\begin{array}{l}\text { Glide energy } \\
\text { (kcal/mol) }\end{array}$ \\
\hline \multirow[t]{4}{*}{ । } & 1 & 5 & -8.485 & -57.409 & -8.409 & -61.051 \\
\hline & 2 & 12 & -8.907 & -57.165 & -8.825 & -63.027 \\
\hline & 3 & 20 & -6.657 & -62.959 & -8.69 & -54.556 \\
\hline & 4 & 23 & -6.795 & -52.624 & -8.301 & -57.817 \\
\hline \multirow[t]{4}{*}{$\|$} & 5 & 12 & -6.627 & -52.907 & -8.361 & -54.128 \\
\hline & 6 & 16 & -7.69 & -57.228 & -8.986 & -54.764 \\
\hline & 7 & 19 & -6.778 & -64.087 & -8.365 & -56.448 \\
\hline & 8 & 26 & -5.426 & -54.725 & -5.982 & -49.251 \\
\hline \multirow[t]{4}{*}{ III } & 9 & N8 & -6.148 & -56.817 & -7.878 & -58.473 \\
\hline & 10 & N9 & -7.425 & -53.041 & -6.748 & -49.725 \\
\hline & 11 & N14 & -5.787 & -47.184 & -7.983 & -50.79 \\
\hline & 12 & N18 & -5.37 & -57.631 & -7.665 & -55.517 \\
\hline \multirow[t]{4}{*}{ IV } & 13 & W12 & -7.736 & -58.249 & -7.781 & -54.771 \\
\hline & 14 & W15 & -5.558 & -52.555 & -7.884 & -51.905 \\
\hline & 15 & W17 & -7.554 & -54.696 & -8.642 & -52.047 \\
\hline & 16 & W20 & -9.686 & -52.697 & -7.703 & -58.783 \\
\hline \multirow[t]{3}{*}{ V } & 17 & $\mathrm{Z24}$ & -7.295 & -47.998 & -7.275 & -45.298 \\
\hline & 18 & $\mathrm{Z27}$ & -5.616 & -41.802 & -7.98 & -42.365 \\
\hline & Std. & $5-\mathrm{Fu}$ & -5.79 & -21.629 & -3.414 & -24.58 \\
\hline
\end{tabular}


Table 3 Docking and anticancer activity results of most active compounds and standard drug

\begin{tabular}{|c|c|c|c|c|c|c|c|}
\hline Series & $\begin{array}{l}\text { Comp. } \\
\text { code }\end{array}$ & Molecular structure & $\begin{array}{l}\mathrm{IC}_{50}(\mu \mathrm{M}) \\
\mathrm{HCT} 116\end{array}$ & Docking score & $\begin{array}{l}\text { Glide } \\
\text { energy } \\
\text { (kcal/mol) }\end{array}$ & Interacting residues & $\begin{array}{l}\text { H-bonding with amino } \\
\text { acids }\end{array}$ \\
\hline I & 12 & & 9.53 & -8.907 & -57.165 & $\begin{array}{l}\text { Val35, Tyr32, Phe176, } \\
\text { Asp173, Ala172, Leu95, } \\
\text { Phe97, Asp98, Tyr 99, } \\
\text { Ala100, Asp103, Ala155, } \\
\text { Leu158, Glu66, Leu70, } \\
\text { Lys 52, Ala50, Ile79, } \\
\text { Val27, Gly28, Arg356 }\end{array}$ & Asp173, Lys52, Ala100 \\
\hline$\|$ & 16 & & 11.97 & -7.69 & -57.228 & $\begin{array}{l}\text { Phe97, Asp98, Tyr99, } \\
\text { Ala100, Val27, Asp103, } \\
\text { His106, Ala155, Asn156, } \\
\text { Leu158, Ala172, Asp173, } \\
\text { Met174, Phe176, Glu66, } \\
\text { Leu70, Ile79, Val35, } \\
\text { Arg356, Tyr32, Ala50, } \\
\text { Lys52 }\end{array}$ & Ala155, Lys52 \\
\hline III & N9 & & 5.85 & -7.425 & -53.041 & $\begin{array}{l}\text { Val35, Tyr32, Arg29, Gly28, } \\
\text { Val27, Arg356, His106, } \\
\text { Asp103, Ala100, Tyr99, } \\
\text { Phe97, Phe176, Asp173, } \\
\text { Ala172, Ala50, Lys52, } \\
\text { Leu158, Asn156, Glu66, } \\
\text { Leu70, Ile79 }\end{array}$ & Tyr32,Val27, Lys52 \\
\hline IV & W20 & & 11.61 & -9.686 & -52.697 & $\begin{array}{l}\text { Lys52, Ala50, lle79, Phe97, } \\
\text { Asp98, Tyr99, Ala100, } \\
\text { Arg356, Asp103, Trp105, } \\
\text { His106, Leu158, Asn156, } \\
\text { Ala155, Tyr32, Val35, } \\
\text { Val27, Asp173, Ala172 }\end{array}$ & Ala100, Ala155 \\
\hline V & $\mathrm{Z24}$ & & 0.46 & -7.275 & -45.298 & $\begin{array}{l}\text { Ala50, Phe97, Asp98, Tyr99, } \\
\text { Ala100, Leu359, Glu357, } \\
\text { Arg356, Lys355, Ile79, } \\
\text { Leu158, Trp105, His106, } \\
\text { Val27, Gly20, Arg29, } \\
\text { Tyr32, Val35, }\end{array}$ & Tyr32, Val27 \\
\hline Std. & $5-\mathrm{Fu}$ & & 8.84 & -5.79 & -21.629 & $\begin{array}{l}\text { Ile79, Ala50, Phe97, Asp98, } \\
\text { Tyr99, Ala100, Arg356, } \\
\text { Leu158, Val35 }\end{array}$ & Asp98, Ala100 \\
\hline
\end{tabular}

developed hydrogen bond with the crucial amino acids (Val534, Thr347, Leu346 and Cys530). The binding mode of compound $\mathbf{1 6}$ have docking score $(-8.986)$ and developed H-bond with amino acids Thr347, Asp351 and Val534. The binding mode of compound N9 exhibited good docking score $(-6.748)$ and prepared hydrogen bond with crucial amino acid Asp351. Compound W20 scored docking score $(-7.703)$ and prepared hydrogen bond with amino acids residues Asp351. Whereas, compound Z24 displayed the good docking score $(-7.275)$ and prepared hydrogen bond within binding pocket. The standard drug (5-fluorouracil) have docking score $(-3.414)$ within the binding pocket. The docking results with interacting residues of the compounds and standard drug are shown in Table 4; binding surface (3D) and ligand interaction (2D) images are shown in Figs. 10, 11, 12, 13, 14, 15. Binding mode of five most active compounds is shown in Figs. 16 and 17. Based on the molecular docking analyses these compounds were evaluated for their in vitro anticancer activity against human breast adenocarcinoma cancer cell line (MCF7) by Sulforhodamine- $B$ assay. The anticancer activity result of these compounds is shown in Tables 3 and 4, Figs. 18 and 19.

Molecular docking results suggest that the selected compounds of heterocyclic benzimidazole can act as of 

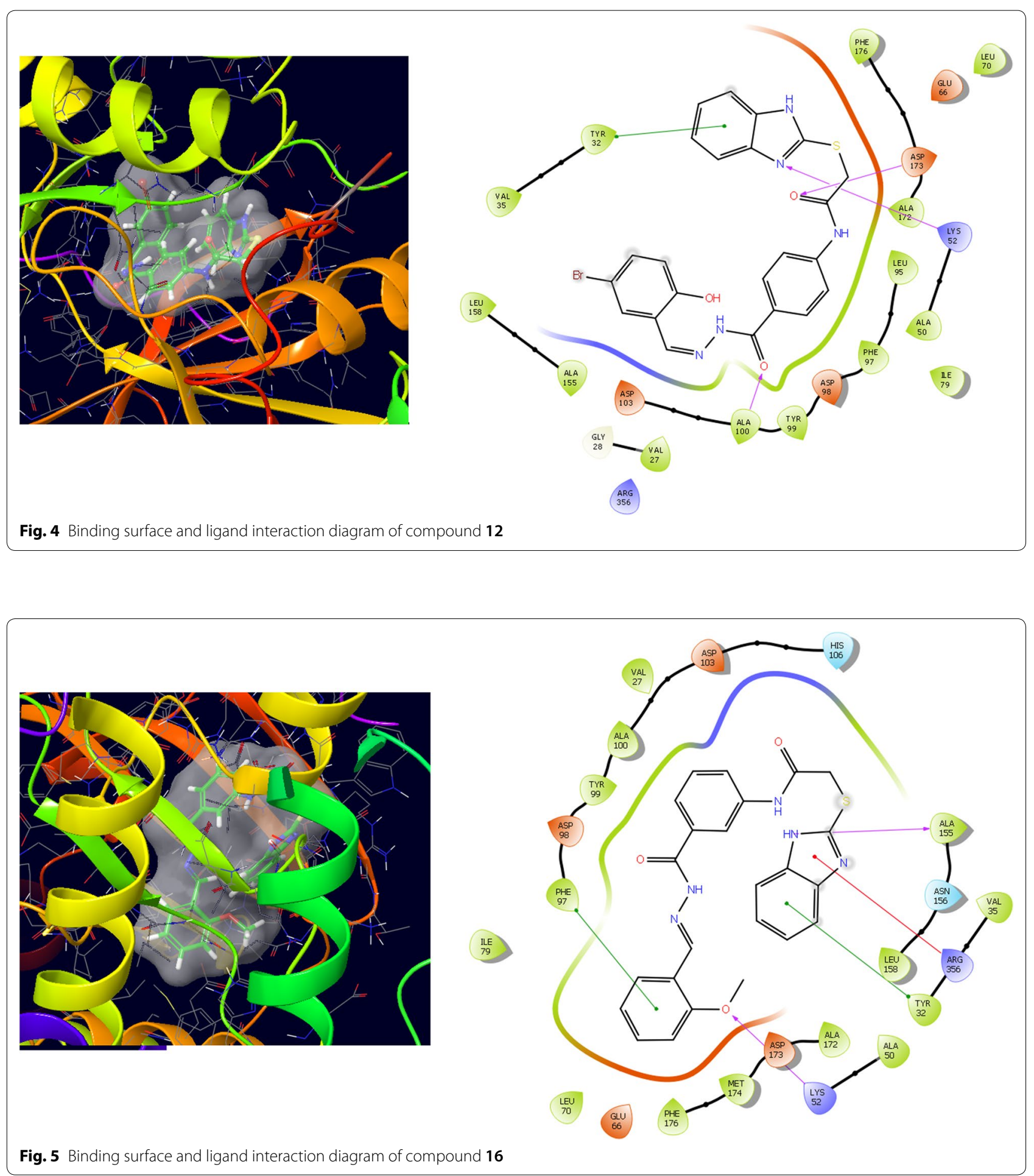

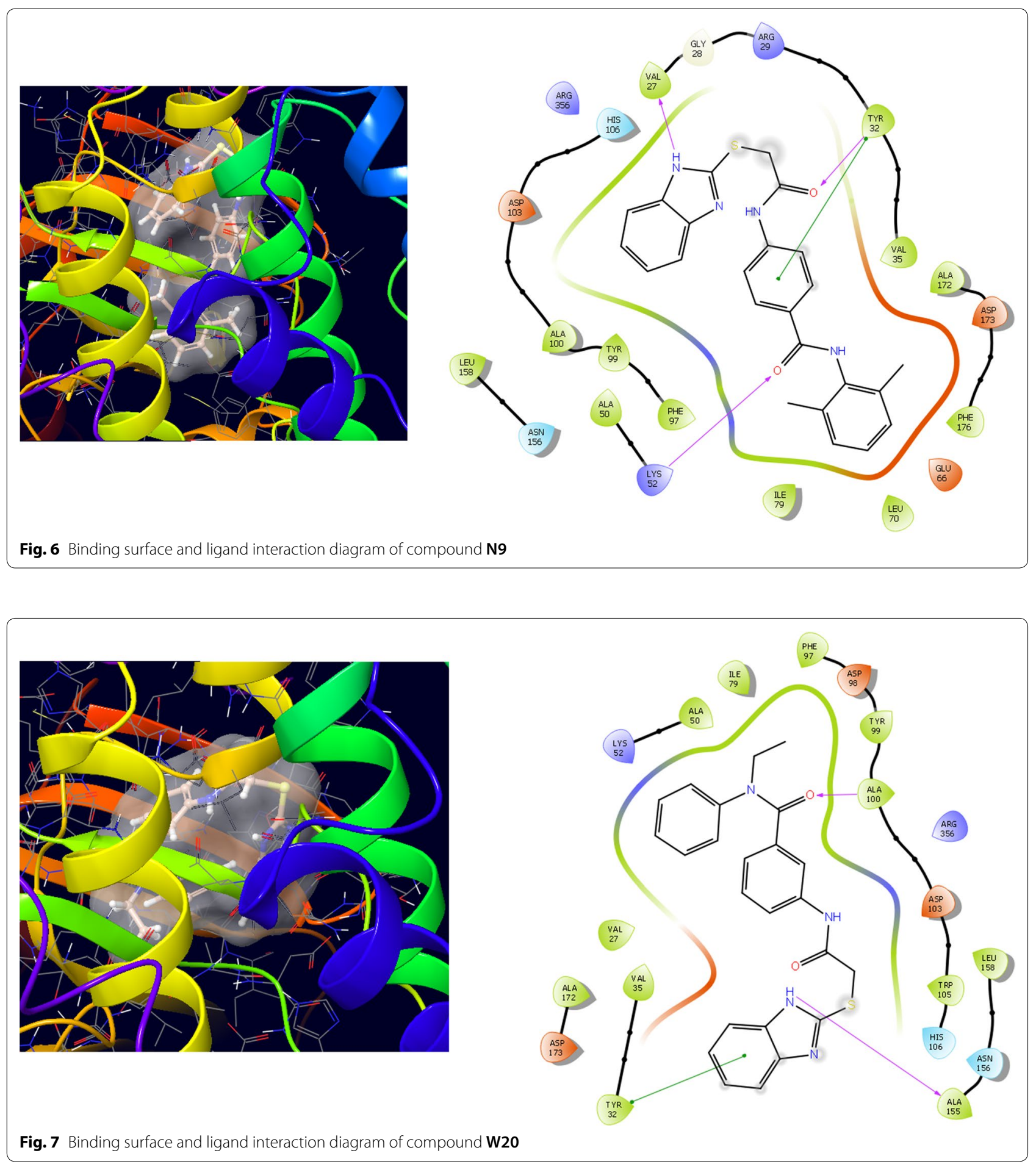

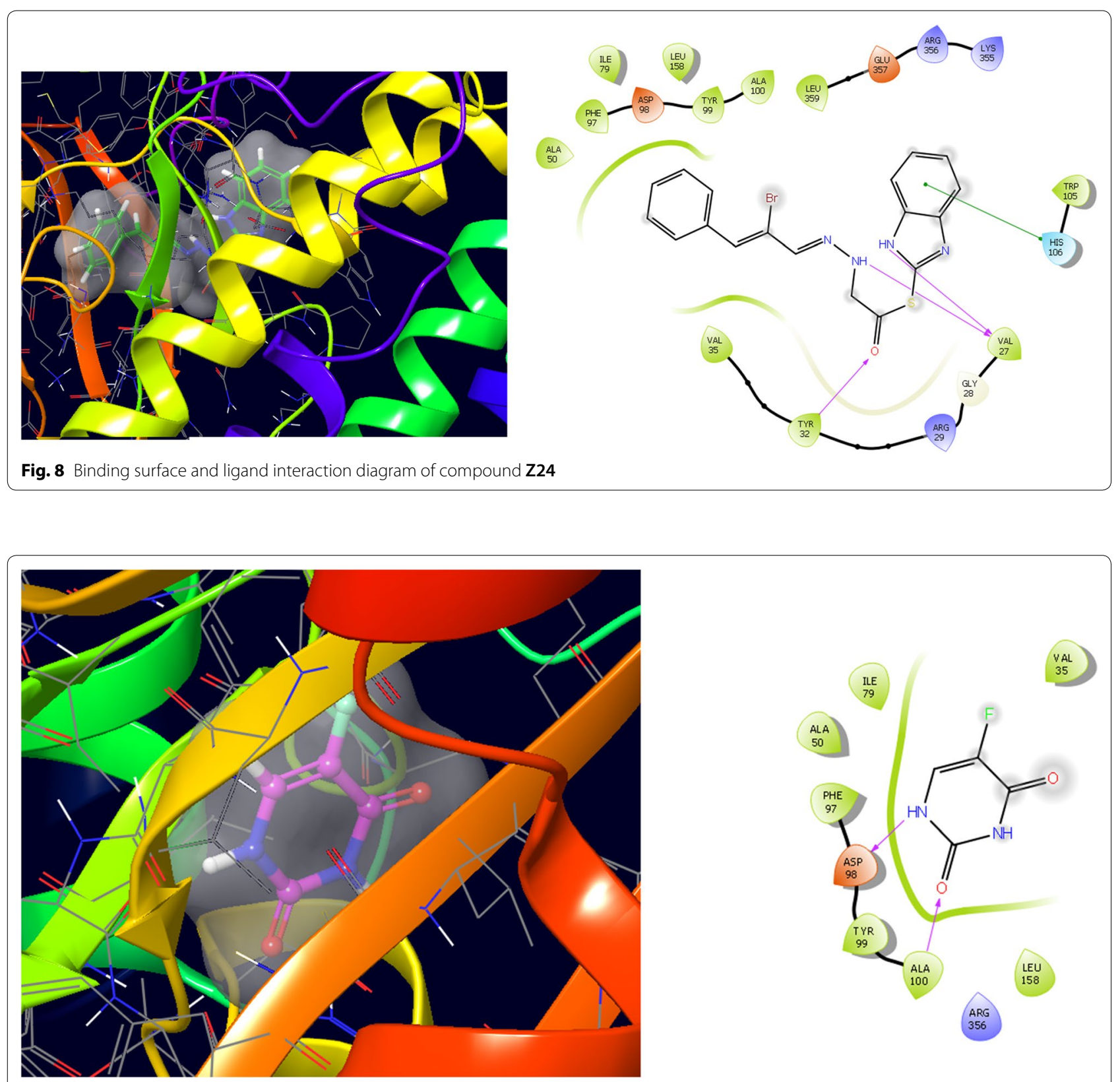

Fig. 9 Binding surface and ligand interaction diagram of 5-fluorouracil 
Table 4 Docking and anticancer activity results of most active compounds and standard drug

\begin{tabular}{|c|c|c|c|c|c|c|c|}
\hline Series & $\begin{array}{l}\text { Comp. } \\
\text { code }\end{array}$ & Molecular structure & $\begin{array}{l}I_{50}(\mu \mathrm{M}) \\
\text { MCF7 }\end{array}$ & $\begin{array}{l}\text { Docking } \\
\text { score }\end{array}$ & $\begin{array}{l}\text { Glide } \\
\text { energy } \\
\text { (kcal/mol) }\end{array}$ & Interacting residues & $\begin{array}{l}\text { H-bonding } \\
\text { with amino acids }\end{array}$ \\
\hline । & 12 & & 10.58 & -8.825 & -63.027 & $\begin{array}{l}\text { Leu539, Leu536, Pro535, Val534, } \\
\text { Val533, Cys530, Lys529, Met528, } \\
\text { Leu525, Glu353, Ala350, Leu349, } \\
\text { Thr347, Leuy346, Met343, Trp383, } \\
\text { Leu384, Leu387, Met388, Leu391, } \\
\text { Arg394 }\end{array}$ & $\begin{array}{l}\text { Val534, Thr347, } \\
\text { Leu346, Cys,530 }\end{array}$ \\
\hline$\|$ & 16 & & 7.05 & -8.986 & -54.764 & $\begin{array}{l}\text { Met343, Leu346, Thr347, Ala350, } \\
\text { Asp351, leu539, Leu536, Pro535, } \\
\text { Val534, Val533, Ile424, Met421, } \\
\text { Phe404, Leu391, Leu387, Hie524, } \\
\text { Leu525, Trp383, Met528, }\end{array}$ & $\begin{array}{l}\text { Thr347, Asp351, } \\
\text { Val534 }\end{array}$ \\
\hline III & N9 & & 1.38 & -6.748 & -49.725 & $\begin{array}{l}\text { Trp383, Leu384, Leu387, Met388, } \\
\text { Leu391, Phe404, Leu428, Met 343, } \\
\text { Leu346, Thr347, Ala350, Asp351, } \\
\text { Leu536, Pro535, Val534, Val533, } \\
\text { Leu525, Gly521, lle424, Met421 }\end{array}$ & Asp351 \\
\hline IV & W20 & & 13.01 & -7.703 & -58.783 & $\begin{array}{l}\text { Trp383, Leu384, Leu387, Met388, } \\
\text { Leu428, Leu391, Phe404, Ile424, } \\
\text { Met421, Gly420, Glu419, Val418, } \\
\text { Leu525, Hie524, Gly521, Met343, } \\
\text { Leu346, Thr347, Ala350, Asp351, } \\
\text { Leu539, Leu536, Val534, Val533 }\end{array}$ & Asp351 \\
\hline V & Z24 & & 0.22 & -7.275 & -45.298 & $\begin{array}{l}\text { Trp383, Leu384, Leu387, Met388, } \\
\text { Leu428, Pye404, Leu391, Met343, } \\
\text { Leu346, Thr347, Ala350, Val418, } \\
\text { Glu419, Gly420, Met421, Ile424, } \\
\text { Gly521, Hie524, Leu525, Met528 }\end{array}$ & - \\
\hline Std. & $5-\mathrm{Fu}$ & O= & 4.61 & -3.414 & -24.58 & $\begin{array}{l}\text { Leu346, Leu349, Ala350, Glu353, } \\
\text { Leu384, Leu387, Met388, Phe404, } \\
\text { Leu391, Arg394 }\end{array}$ & Glu353, Arg394 \\
\hline
\end{tabular}

great interest in successful chemotherapy. The selected protein data bank i.e. (PDB id: 5FGK and 3ERT) for human colorectal carcinoma and breast adenocarcinoma cancer cell lines may be the good target protein of benzimidazole molecules for their anticancer activity. Based on the docking analysis it is suggested that more structural modifications are required in molecules 12, 16, N9, W20 and Z2 to make them more potent toward cancer cell. The structure activity relationship study based on molecular doking is given in Figs. 20 and 21.

\section{ADME results}

Lipinski's rule of five is a rule of thumb to evaluate drug likeness or determine if a chemical compound with a certain pharmacological or biological activity has chemical properties and physical properties that would make it a likely orally active drug in humans. The rule describes molecular properties important for a drug's pharmacokinetics in the human body, including their absorption, distribution, metabolism, and excretion (ADME). The rule is important to keep in mind during drug discovery when a pharmacologically active lead 

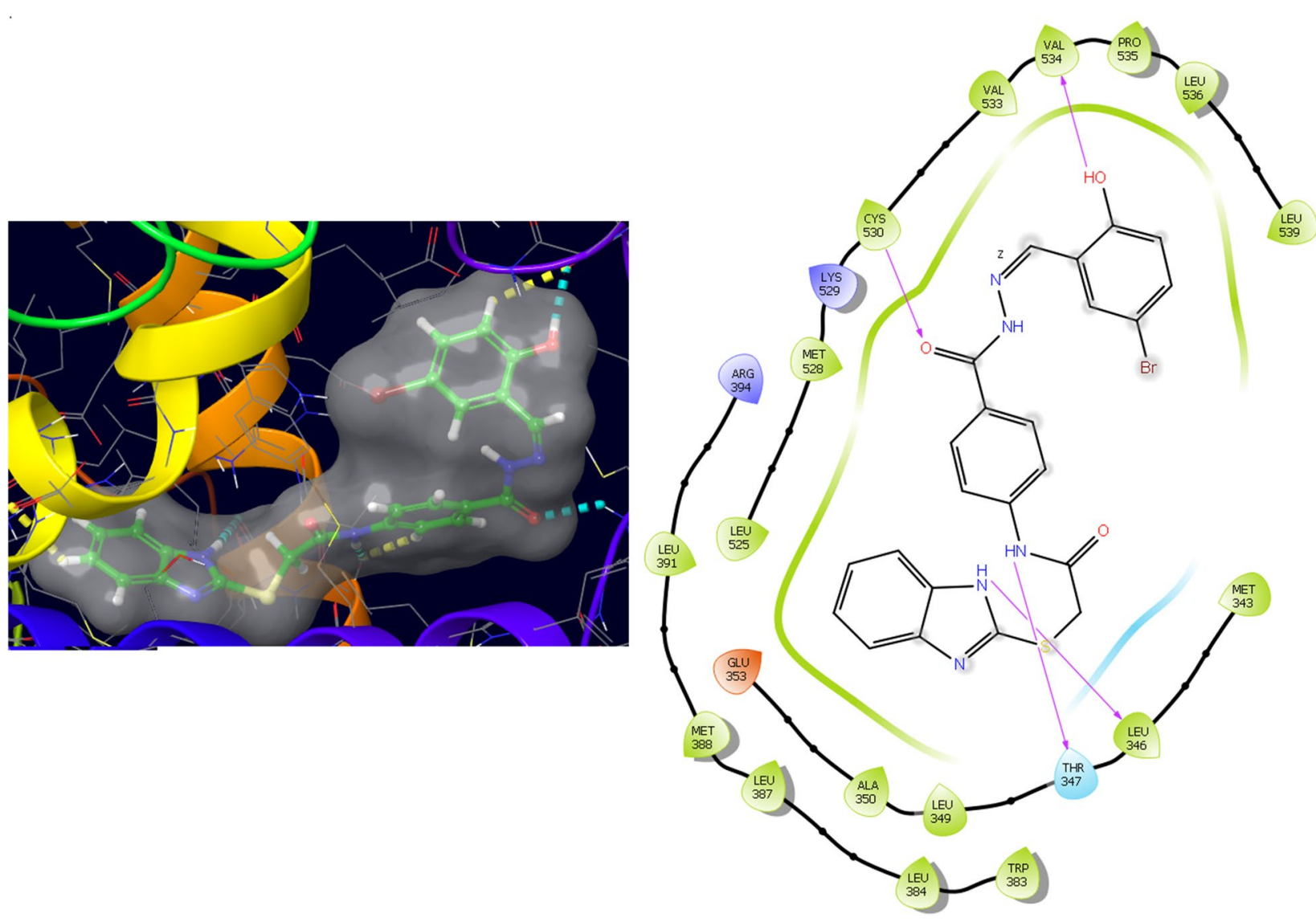

Fig. 10 Binding surface and ligand interaction diagram of compound 12

structure is optimized step-wise to increase the activity and selectivity of the compound as well as to ensure drug-like physicochemical properties are maintained as described by Lipinski's rule which states that (i) no more than 5 hydrogen bond donors, (ii) no more than 10 hydrogen bond acceptors, (iii) a molecular mass less than 500 daltons, (iv) an octanol-water partition coefficient $\log \mathrm{P}$ not greater than 5 (https://en.wikipedia.
org/wiki/Lipinski\%27s_rule_of_five). Now these days, computational approaches are employed to determine the ADME of the drug molecules. ADME modeling has attracted the considerable attention of the pharmaceuticals researchers for the drug discovery as they are high-throughput in nature and cost effective [34]. ADME study of the selected compounds was performed using QikProp module of Maestro version 11.5. Around 

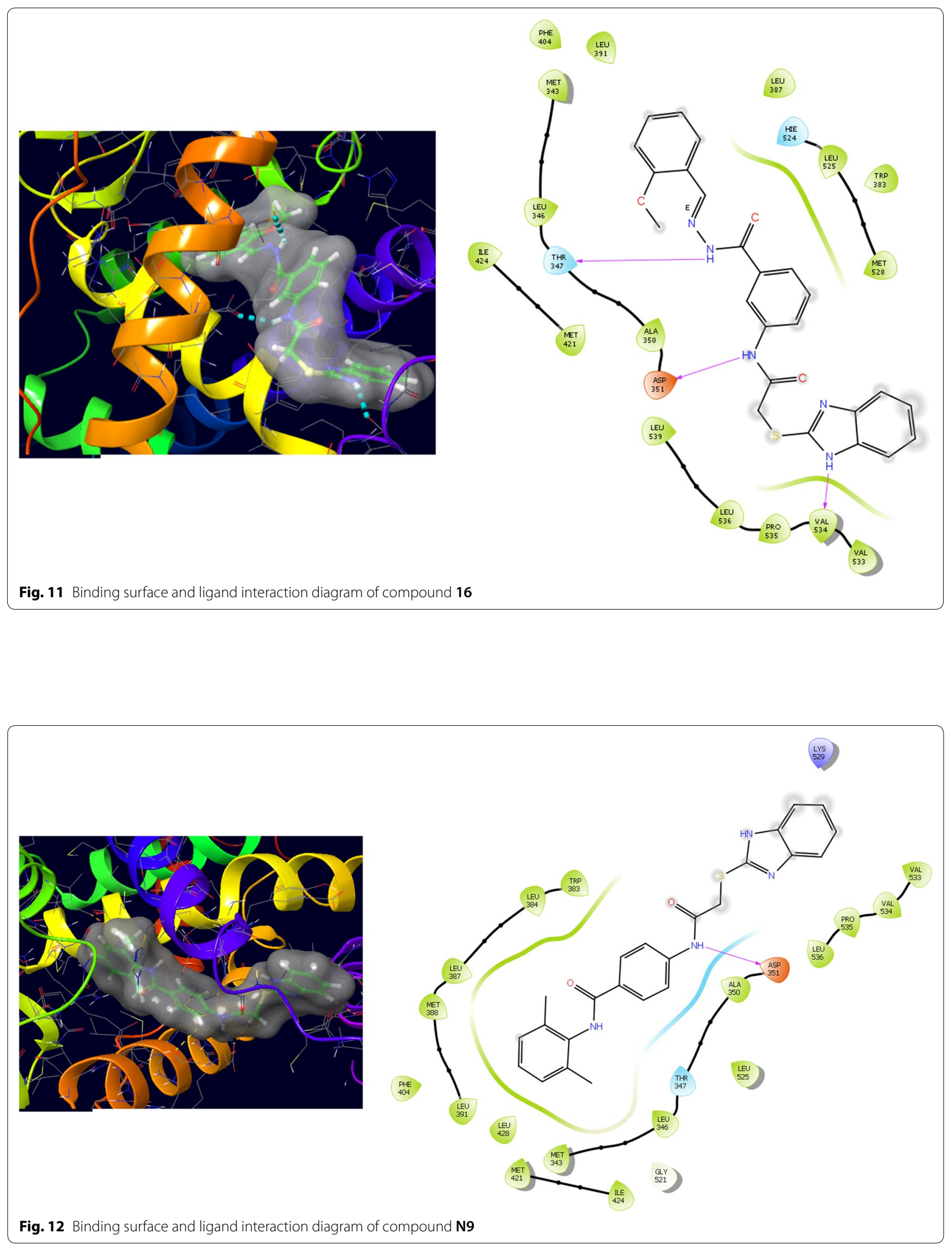

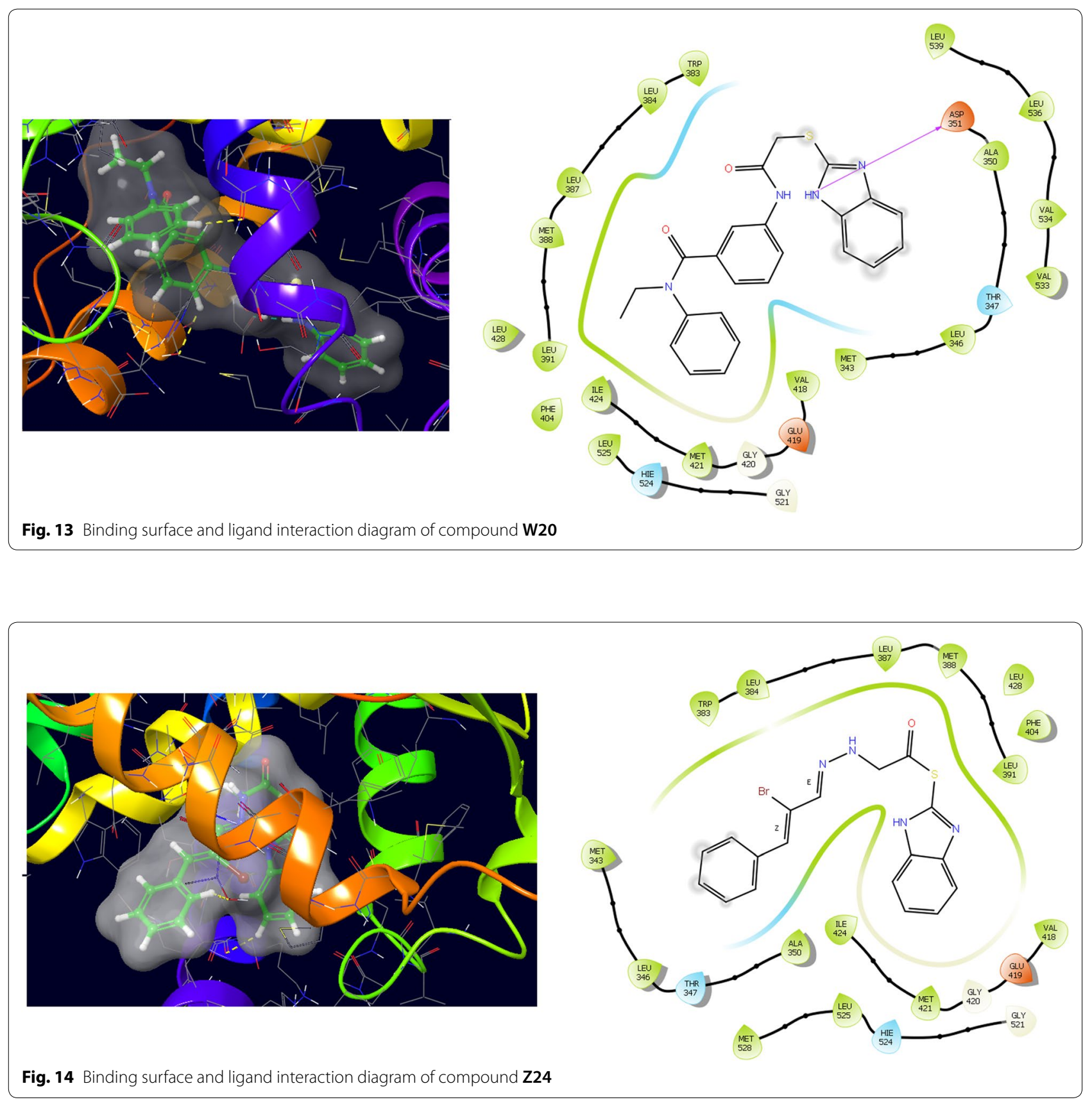

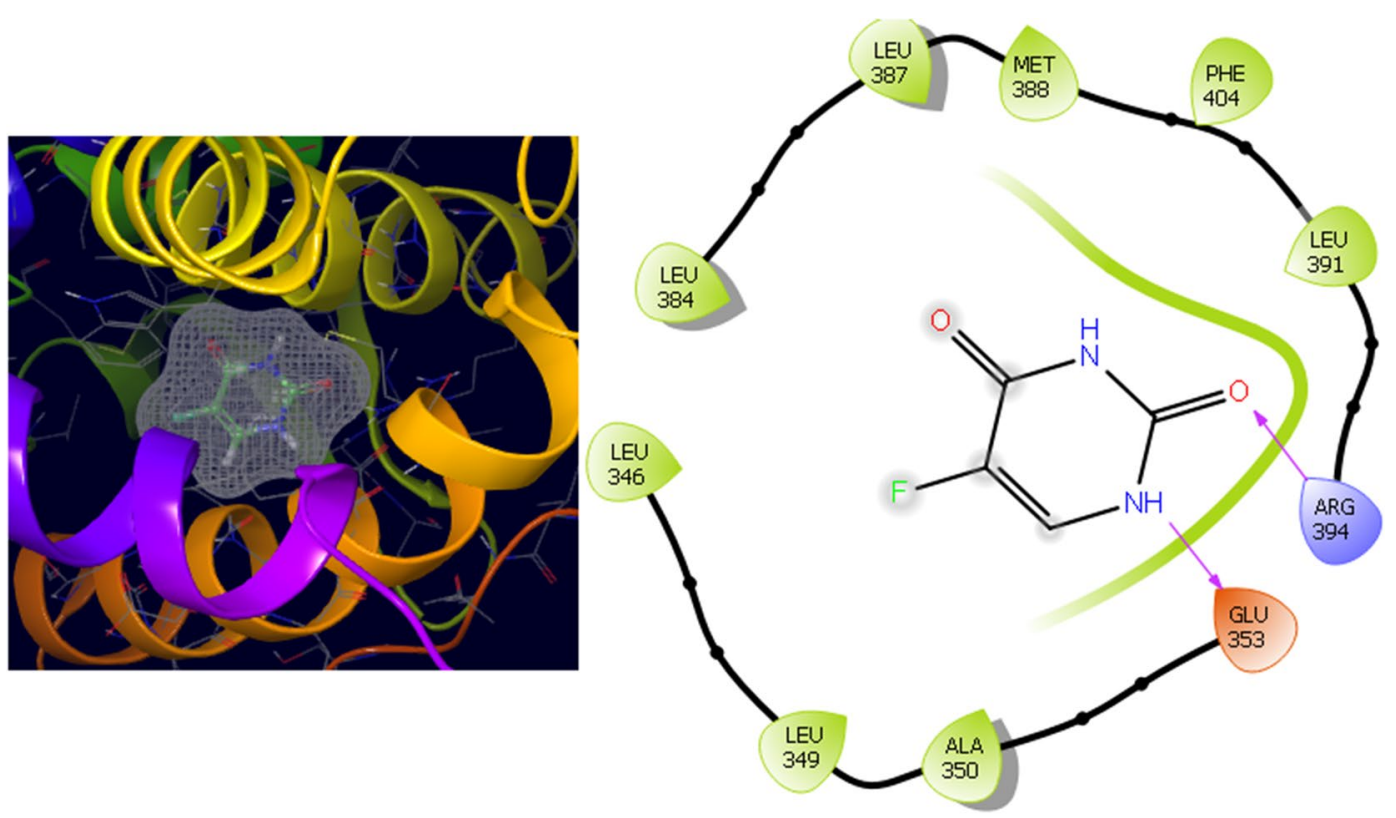

Fig. 15 Binding surface and ligand interaction diagram of 5-fluorouracil

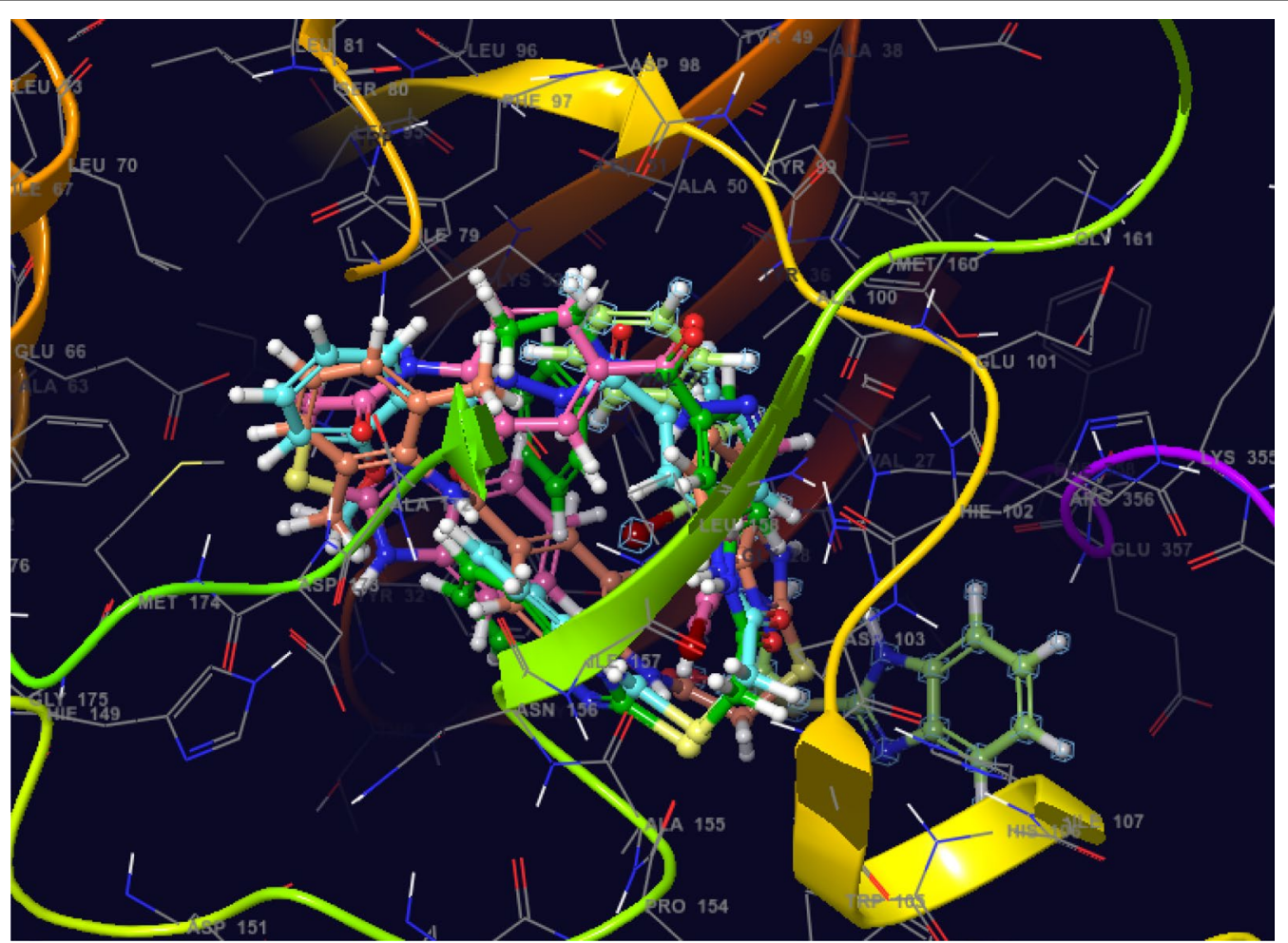

Fig. 16 Binding mode of five most active compounds $(\mathbf{1 2}, \mathbf{1 6}, \mathbf{N} \mathbf{9}, \mathbf{W} \mathbf{2 0}$ and $\mathbf{Z 2 4})$ into the CDK-8 active site 


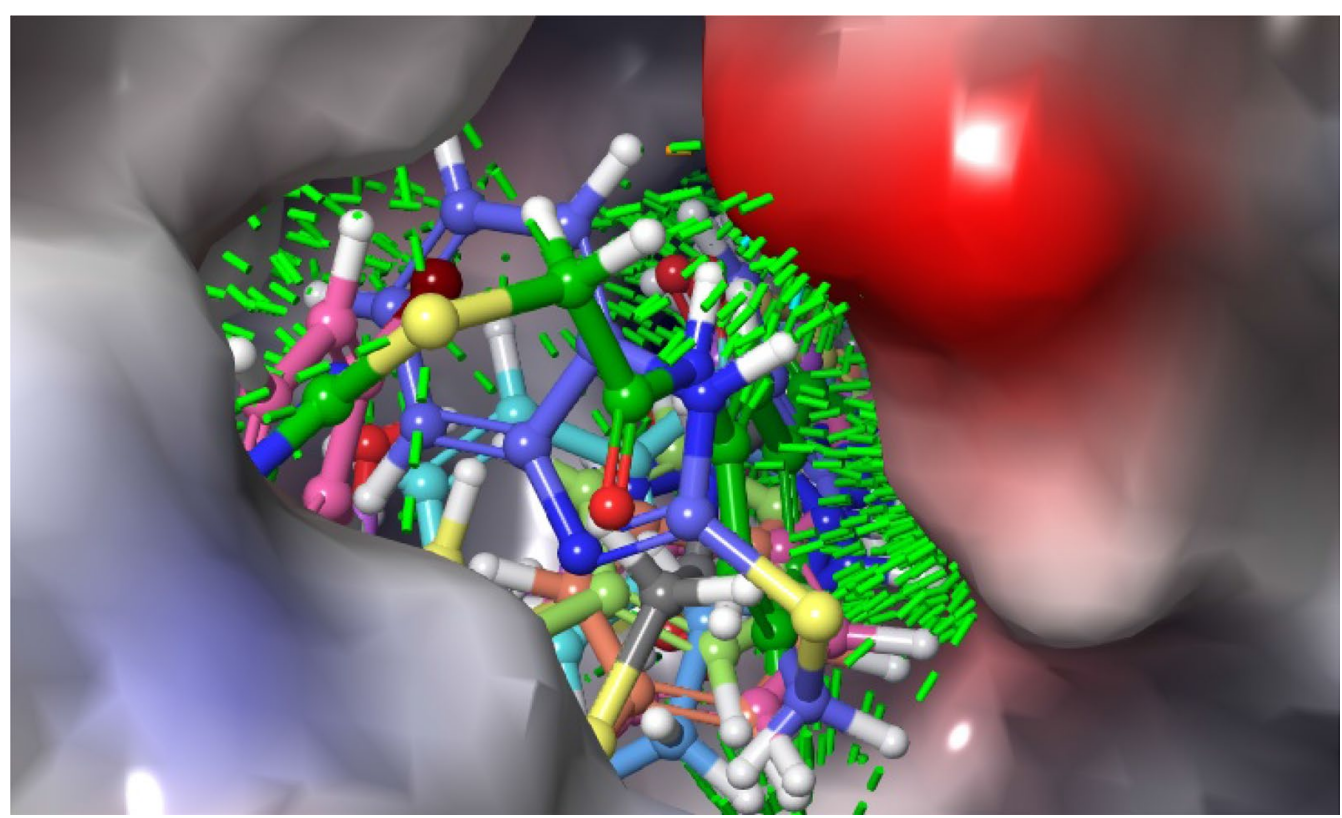

Fig. 17 Binding mode of five most active compounds $(\mathbf{1 6}, \mathbf{1 2}, \mathbf{N} \mathbf{9}, \mathbf{W} \mathbf{2 0}$ and $\mathbf{Z 2 4})$ into the $3 E R T$ active site
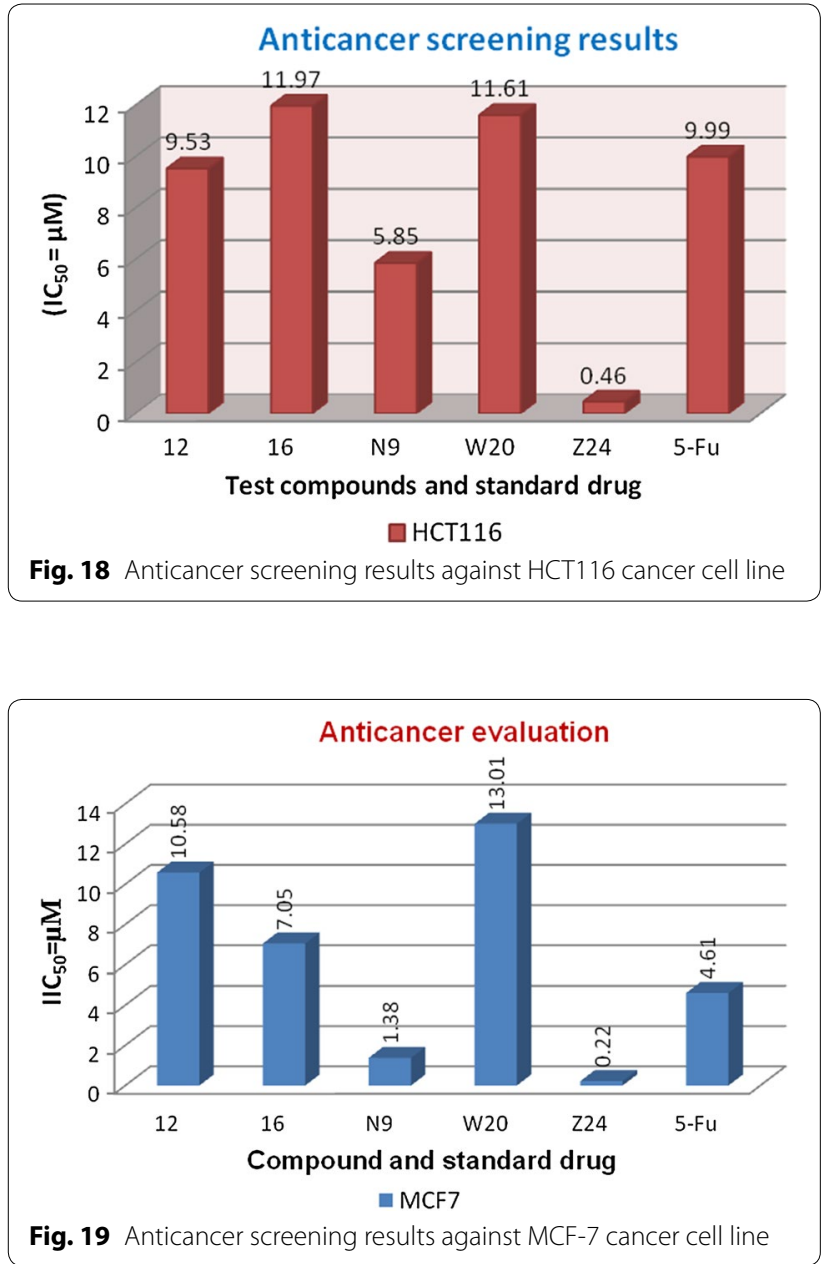

eleven physically relevant and pharmacologically significant parameters of the most active compounds 16, N9 and $\mathbf{W} 20$ were determined. The ADME results of the selected heterocyclic benzimidazole compounds 16, N9 and W20 displayed the significant results within the close agreement with the Lipinski's rule of five and Qikprop rule within the range i.e. Molecular weight of the molecule (mol. MW $\leq 500$ ), Predicted octanol/ water partition coefficient $(\mathrm{QPlogPo} / \mathrm{w}=-2.0$ to -6.5$)$, $(\mathrm{QP} \log \mathrm{Pw}=4.0$ to -45.0$)$, Predicted water/gas partition coefficient ( $\mathrm{QP} \log \mathrm{Kp}=-8.0$ to -1.0$)$, Predicted brain/ blood partition coefficient $(\mathrm{QP} \log B \mathrm{~B}=-3.0$ to -1.2$)$, donor HB (0.0 to -6.0$)$, accept HB (2.0 to -20.0$)$, human oral absorption (1, 2 or 3 ), percent human oral absorption (0 to 100), Predicted water/gas partition coefficient thus making these compounds as suitable drug candidate. The ADME results are shown in the in Table 5.

\section{Conclusion}

In the present work the molecular docking study of the data set of heterocyclic benzimidazole molecules was performed by Maestro version 11.5. In this study we have used CDK8 for human colorectal carcinoma cancer and ER-alpha for breast adenocarcinoma cancer cell lines and identified best anticancer target. Molecular docking results displayed that compounds $(\mathbf{1 2}, \mathbf{1 6}, \mathbf{N 9}, \mathbf{W} 20$ and Z24) showed the better docked score with moderate to better antiproliferative potency towards cancer cell line within the binding pocket of receptor and comparable to 


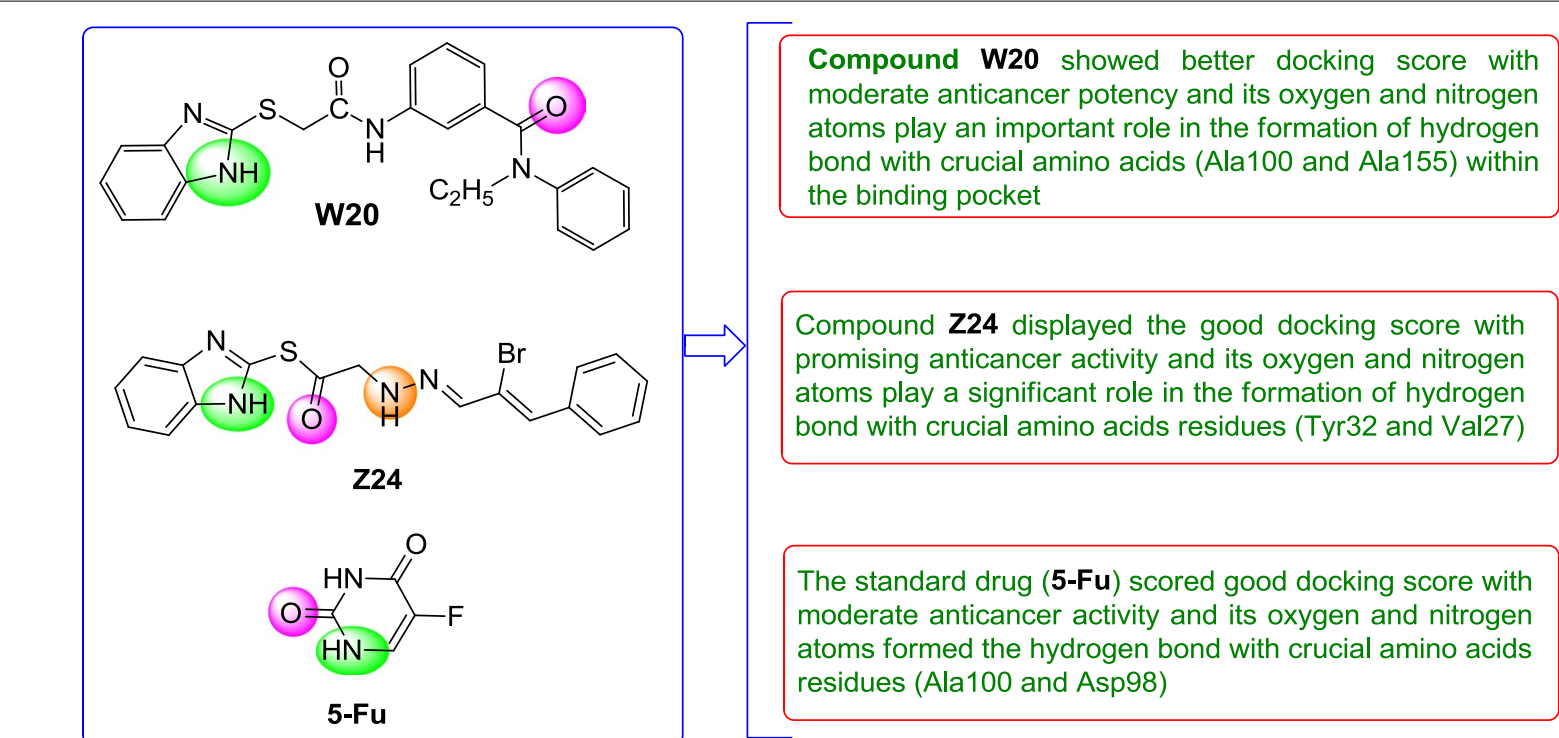

Fig. 20 Structure activity relationship based on molecular docking study for HCT116 cell line

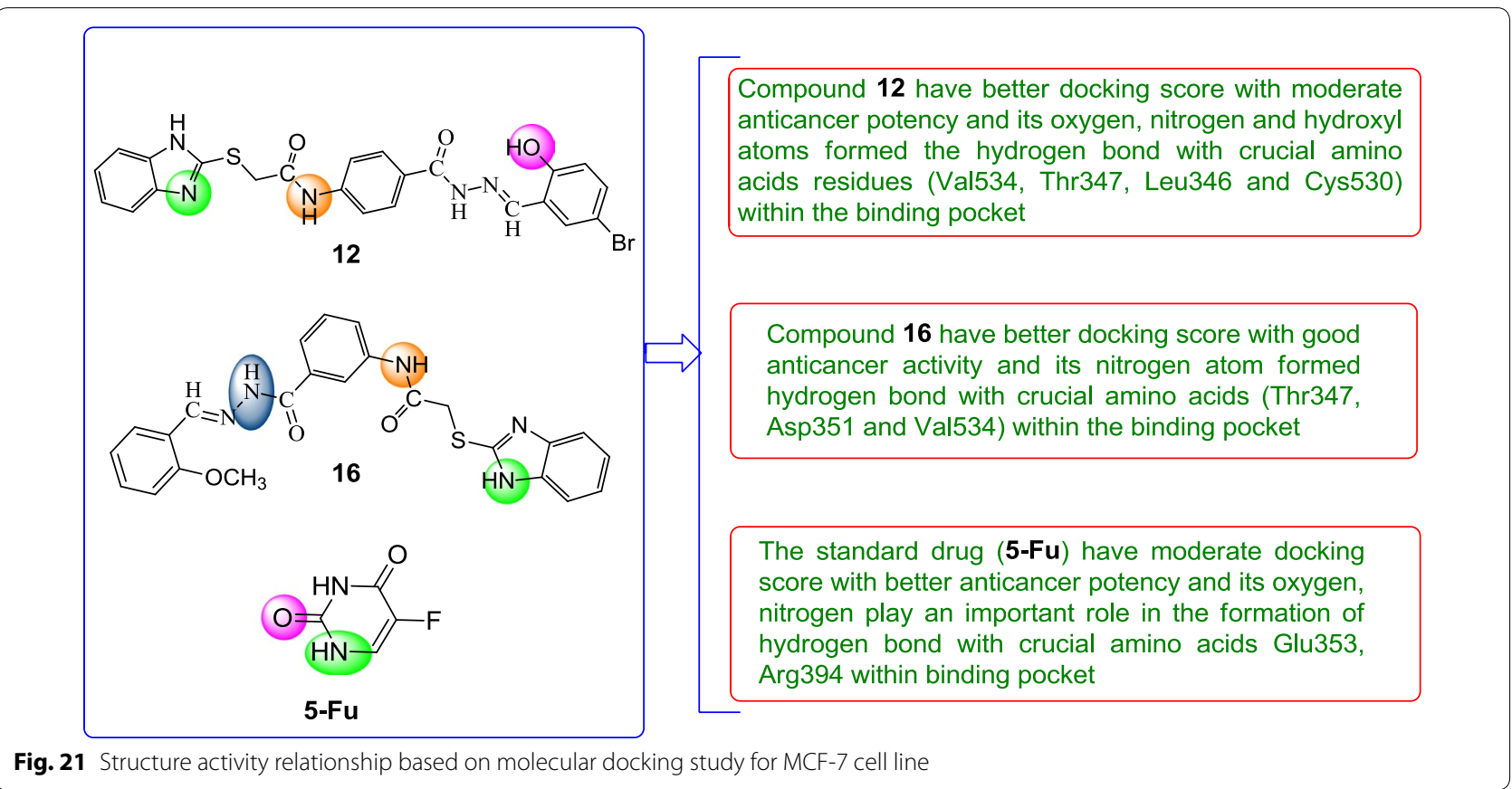




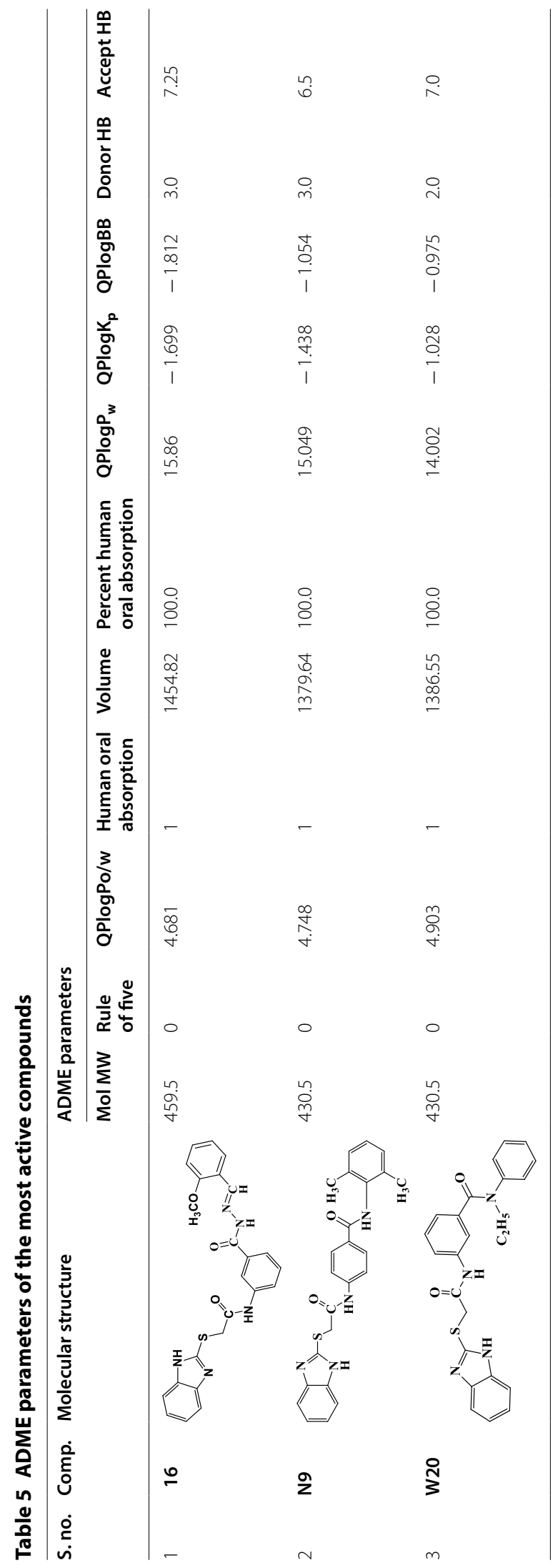


the standard drug. The compounds 16, N9 and W20 also showed good ADME properties within the close agreement of the Lipinski's rule of five and Qikprop rule within the range and thus making these compounds as suitable drug molecules.

\author{
Abbreviations \\ ADME: absorption, distribution, metabolism and excretion; CDK8: cyclin \\ dependent kinase 8; ER-alph: estrogen receptor alpha; HCT116: human \\ colorectal carcinoma 116; MCF-7: Michigan Cancer Foundation-7; $\mu \mathrm{M}$ : micro \\ mole; PDB: protein data bank; XP: extra precision; 5-Fu: 5-fluorouracil; $\mathrm{H}$-bond: \\ hydrogen-bond; 2D: 2 dimensional; 3D: 3 dimensional; RMSD: root-mean- \\ square deviation.
}

\section{Acknowledgements}

The authors are thankful to Head, Department of Pharmaceutical Sciences, Maharshi Dayanand University, Rohtak, for providing necessary facilities to carry out this research work.

\section{Authors' contributions}

BN, ST: performed the molecular docking study; SK: performed ADME study of the anticancer active compounds and KR, SML, SAAS, VM: performed antiproliferative activity of synthesized compounds. All authors read and approved the final manuscript.

\section{Funding}

Not applicable.

\section{Availability of data and materials}

We have presented all our main data in the form of tables and figures.

\section{Competing interests}

The authors declare that they have no competing interests.

\begin{abstract}
Author details
${ }^{1}$ Faculty of Pharmaceutical Sciences, Maharshi Dayanand University, Rohtak 124001, India. ${ }^{2}$ Faculty of Pharmacy, Universiti Teknologi MARA (UiTM), 42300 Bandar Puncak Alam, Selangor Darul Ehsan, Malaysia. ${ }^{3}$ Collaborative Drug Discovery Research (CDDR) Group, Pharmaceutical Life Sciences Community of Research, Universiti Teknologi MARA (UiTM), 40450 Shah Alam, Selangor Darul Ehsan, Malaysia. ${ }^{4}$ Atta-ur-Rahman Institute for Natural Products Discovery (AuRIns), Universiti Teknologi MARA, Puncak Alam Campus, 42300 Bandar Puncak Alam, Selangor Darul Ehsan, Malaysia. ${ }^{5}$ Department of Pharmacology and Toxicology, College of Pharmacy, Qassim University, Buraidah 51452, Kingdom of Saudi Arabia.
\end{abstract}

Received: 5 April 2019 Accepted: 29 June 2019

Published online: 11 July 2019

\section{References}

1. Abonia R, Cortes E, Insuasty B, Quiroga J, Nogueras M, Cobo J (2011) Synthesis of novel 1,2,5-trisubstituted benzimidazoles as potential antitumor agents. Eur J Med Chem 46:4062-4070

2. Patil A, Ganguly S, Surana S (2010) Synthesis and antiulcer activity of 2-[5-substituted-1-H-benzo(d)imidazol-2-yl sulfinyl]methyl-3-substituted quinazoline-4-(3H) ones. J Chem Sci 122(3):443-450

3. Kus C, Ayhan-Kılcıgil G, Ozbey S, Kaynak FB, Kaya M, Coban T, Can-Eke B (2008) Synthesis and antioxidant properties of novel $\mathrm{N}$-methyl-1,3,4thiadiazol-2-amine and 4-methyl-2H-1,2,4-triazole-3(4H)-thione derivatives of benzimidazole class. Bioorg Med Chem 16:4294-4303

4. Ziolkowska NE, Michejda CJ, Bujacz GD (2009) Crystal structures of HIV-1 nonnucleoside reverse transcriptase inhibitors: N-benzyl-4-methyl-benzimidazoles. J Mol Strut 930:157-161

5. Tahlan S, Narasimhan B, Lim SM, Ramasamy K, Mani V, Shah SAA (2018) 2-Mercaptobenzimidazole Schiff bases: design, synthesis, antimicrobial studies and anticancer activity on HCT-116 cell line. Mini-Rev Med Chem. https://doi.org/10.2174/1389557518666181009151008

6. Hernandez-Covarrubias C, Vilchis-Reyes MA, Yepez-Mulia L, Sanchez-Diaz R, Navarrete-Vazquez G, Hernandez-Campos A, Castillo R, HernandezLuis F (2012) Exploring the interplay of physicochemical properties, membrane permeability and giardicidal activity of some benzimidazole derivatives. Eur J Med Chem 52:193-204

7. Tahlan S, Narasimhan B, Lim SM, Ramasamy K, Mani V, Shah SAA (2018) Design, synthesis, SAR study, antimicrobial and anticancer evaluation of novel 2-mercaptobenzimidazole azomethine derivatives. Mini-Rev Med Chem. https://doi.org/10.2174/1389557518666180903151849

8. Lavrador-Erb K, Ravula SB, Yu J, Zamani-Kord S, Moree WJ, Petroski RE, Wen J, Malany S, Hoare SRJ, Madan A, Crowe PD, Beaton G (2010) The discovery and structure-activity relationships of 2-(piperidin-3-yl)-1 Hbenzimidazoles as selective, CNS penetrating $\mathrm{H}_{1}$-antihistamines for insomnia. Bioorg Med Chem Lett 20:2916-2919

9. Tahlan S, Ramasamy K, Lim SM, Shah SAA, Mani V, Narasimhan B (2019) 4-(2-(1H-Benzo[d]imidazol-2-ylthio)acetamido)-N-(substituted phenyl) benzamides: design, synthesis and biological evaluation. Chem Cent J 13(12):1-16

10. Chu X-J, DePinto W, Bartkovitz D, So S-S, Vu BT, Packman K, Lukacs C, Ding Q, Jiang N, Wang K, Goelzer P, Yin X, Smith MA, Higgins BX, Chen Y, Xiang Q, Moliterni J, Kaplan G, Graves B, Lovey A, Fotouhi N (2006) Discovery of [4-amino-2-(1-methanesulfonyl-piperidin-4-ylamino)pyrimidin-5-yl] (2,3-difluoro-6-methoxyphenyl)methanone (R547), a potent and selective cyclin-dependent kinase inhibitor with significant in vivo antitumor activity. J Med Chem 49:6549-6560

11. Koehler MFT, Bergeron P, Blackwood EM, Bowman K, Clark KR, Firestein R, Kiefer JR, Maskos K, McCleland ML, Orren L, Salphati L, Schmidt S, Schneider FV, Wu J, Beresini MH (2016) Development of a potent, specific CDK8 kinase inhibitor which phenocopies CDK8/19 knockout cells. ACS Med Chem Lett 7:223-228

12. Kalra S, Joshi G, Munshi A, Kumar R (2017) Structural insights of cyclin dependent kinases: implications in design of selective inhibitors. Eur J Med Chem 142:424-458

13. Kumar S, Lim SM, Ramasamy K, Vasudevan M, Shah SAA, Selvaraj M, Narasimhan B (2017) Synthesis, molecular docking and biological evaluation of bis-pyrimidine Schiff base derivatives. Chem Cent J 11(89):1-16

14. Wang Z-Y, Yin L (2015) Estrogen receptor alpha-36 (ER-a36): a new player in human breast cancer. Mol Cell Endocrinol 418(3):193-206

15. Kumar R, Zakharov MN, Khan SH, Miki R, Jang H, Toraldo G, Singh R, Bhasin S, Ravi J (2011) The dynamic structure of the estrogen receptor. J Amino Acids 2011:1-7

16. Kumar S, Narasimhan B, Lim SM, Ramasamy K, Mani V, Shah SAA (2019) Design, synthesis and biological potential of 5-(2-amino-6-(3/4bromophenyl)pyrimidin-4-yl) benzene-1,3-diol scaffolds as promising antimicrobial and anticancer agents. Mini-Rev Med Chem. https://doi. org/10.2174/1389557518666181009141924

17. Wang J, Urban L (2004) The impact of early ADME profiling on drug discovery and development strategy. Drug Discov World Fall 5(4):73-86

18. Li AP (2001) Screening for human ADME/Tox drug properties in drug discovery. Res Focus 6(7):357-366

19. Wang Y, Xing J, Xu Y, Zhou N, Peng J, Xiong Z, Liu X, Luo X, Luo C, Chen $K$, Zheng $M$, Jiang $H$ (2015) In silico ADME/T modelling for rational drug design. Q Rev Biophys. https://doi.org/10.1017/s0033583515000190:1-28

20. Tahlan S, Ramasamy K, Lim SM, Shah SAA, Mani V, Narasimhan B (2018) Design, synthesis and therapeutic potential of 3-(2- $(1 \mathrm{H}$-benzo[d]imidazol2-ylthio) acetamido)- $\mathrm{N}$-(substituted phenyl)benzamide analogues. Chem Cent J 12(139):1-12

21. Tahlan S, Kumar S, Ramasamy K, Lim SM, Shah SAA, Mani V, Pathania $R$, Narasimhan B (2019) Design, synthesis and biological profile of heterocyclic benzimidazole analogues as prospective antimicrobial and antiproliferative agents. BMC Chem 13(50):1-15

22. Driessche GVD, Fourches D (2017) Adverse drug reactions triggered by the common HLA-B*57:01 variant: a molecular docking study. J Cheminform 9(13):1-17

23. Sastry GM, Adzhigirey M, Day T, Annabhimoju R, Sherman W (2013) Protein and ligand preparation: parameters, protocols and influence on virtual screening enrichments. J Comput Aid Mol Des 27(3):221-234

24. Kumar S, Singh J, Narasimhan B, Shah SAA, Lim SM, Ramasamy K, Mani V (2018) Reverse pharmacophore mapping and molecular docking studies 
for discovery of GTPase HRas as promising drug target for bis-pyrimidine derivatives. Chem Cent J 12(106):1-11

25. Sharma V, Sharma PC, Kumar V (2016) In silico molecular docking analysis of natural pyridoacridines as anticancer agents. Adv Chem 2016:1-9

26. Singh J, Kumar M, Mansuri R, Sahoo GC, Deep A (2016) Inhibitor designing, virtual screening and docking studies for methyltrans-ferase: a potential target against dengue virus. J Pharm Bioallied Sci 8(3):188-194

27. Friesner RA, Murph RB, Repasky MP, Frye LL, Greenwood JR, Halgren TA, Sanschagrin PC, Mainz DT (2006) Extra precision glide: docking and scoring incorporating a model of hydrophobic enclosure for protein-ligand complexes. J Med Chem 49:6177-6196

28. Lenselink EB, Louvel J, Forti AF, van Veldhoven JPD, de Vries H, MulderKrieger T, McRobb FM, Negri A, Goose J, Abel R, van Vlijmen HWT, Wang L, Harder E, Sherman W, IJzerman AP, Beuming T (2016) Predicting binding affinities for GPCR ligands using free-energy perturbation. ACS Omega 1:293-304

29. Skehan P, Storeng R, Scudiero D, Monks A, McMahon J, Vistica D, Warren JT, Bokesch H, Kenney S, Boyd MR (1990) New colorimetric cytotoxicity assay for anticancer-drug screening. J Natl Cancer Inst 82:1107-1112

30. Bhullar KS, Lagarón NO, McGowan EM, Parmar I, Jha A, Hubbard BP, Rupasinghe HPV (2018) Kinase-targeted cancer therapies: progress, challenges and future directions. Mol Cancer 17(48):1-20
31. Shaik TB, Malik SM, Seddigid ZS, Routhu SR, Kamala A (2017) Evaluation of anticancer and anti-mitotic properties of quinazoline and quinazolinobenzothiadiazine derivatives. http://dx.doi.org/10.1101/108654

32. Hernández-Santoyo A, Tenorio-Barajas AY, Altuzar V, Vivanco-Cid H, Mendoza-Barrera C (2013) Protein-protein and protein-ligand docking. Protein engineering-technology and application, Tomohisa Ogawa. IntechOpen. https://doi.org/10.5772/56376

33. Bassyouni F, El Hefnawi M, El Rashed A, Rehim MA (2017) Molecular modeling and biological activities of new potent antimicrobial, antiinflammatory and anti-nociceptive of 5-nitro indoline-2-one derivatives. Drug Des 6(2):1-6

34. Sharma D, Kumar S, Narasimhan B, Ramasamy K, Lim SM, Shah SAA, Mani V (2019) 4-(4-Bromophenyl)-thiazol-2-amine derivatives: synthesis, biological activity and molecular docking study with ADME profile. BMC Chem 13(60):1-16

\section{Publisher's Note}

Springer Nature remains neutral with regard to jurisdictional claims in published maps and institutional affiliations.
Ready to submit your research? Choose BMC and benefit from:

- fast, convenient online submission

- thorough peer review by experienced researchers in your field

- rapid publication on acceptance

- support for research data, including large and complex data types

- gold Open Access which fosters wider collaboration and increased citations

- maximum visibility for your research: over $100 \mathrm{M}$ website views per year

At BMC, research is always in progress.

Learn more biomedcentral.com/submissions 